\title{
TRANSFORMAÇÃO DE GENOMAS PLASTIDIAIS DE TOMATE E FUMO VISANDO A MODIFICAÇÃO DO METABOLISMO DE TOCOFERÓIS
}

\author{
IRVING JOSEPH BERGER \\ Engenheiro Agrônomo
}

Orientador: Prof. Dr. Ricardo Antunes de Azevedo

Tese apresentada à Escola Superior de Agricultura "Luiz de Queiroz", Universidade de São Paulo, para obtenção do título de Doutor em Agronomia, Área de Concentração: Genética e Melhoramento de Plantas.

\author{
PIRACICABA \\ Estado de São Paulo - Brasil \\ Abril - 2005
}




\section{ERRATA}

BERGER, I.J. Transformação de genomas plastidiais de tomate e fumo visando a modificação do metabolismo de tocoferóis. Piracicaba, 2005. 70p. Tese (doutorado em Agronomia). Escola Superior de Agricultura "Luiz de Queiroz", Universidade de São Paulo.

\begin{tabular}{|c|l|l|l|}
\hline Página & Linha & \multicolumn{1}{|c|}{ Onde se lê } & \multicolumn{1}{c|}{ Leia-se } \\
\hline 5 & 26 & John Hopkins & Johns Hopkins \\
\hline 14 & 01 & (i) à necessidade de compartimentalização & (i) à compartimentalização \\
\hline 22 & 27 & macho-esterilidade & infertilidade \\
\hline 24 & 11 & Análise dos níveis de transcrição... & Desconsiderar metodologia \\
\hline 34 & 05 & geneticamente transformadas & potencialmente transformadas \\
\hline 41 & Fig 12 & & A e B: repetições \\
\hline 41 & Fig 13 & & A e B: repetições \\
\hline 42 & Fig 14 & & A e B: repetições \\
\hline
\end{tabular}

\section{Referências faltantes:}

CHO, E.A.; LEE, C.A.; KIM, Y.S.; BAEK, S.H.; DE LOS REYES, B.G.; YUN, S,J. Expression of gamma-tocopherol methyltransferase transgene improves tocopherol composition in lettuce (Latuca sativa L.). Molecular Cells, v.28; p.16-22, 2005.

RIPPERT, P.; SCIMEMI, C.; DUBALD, M.; MATRINGE, M. Enginnering plant shikimate pathway for production of tocotrienol and improving herbicide resistance. Plant Physiology, v.134, p.92100, 2004.

RUPEREZ, F.J.; MARTIN, D.; HERRERA, E.; BARBAS, C. Chromatographic analysis of alphatocopherol and related compounds in various matrices. Journal of Chromatography A, v. 23, p.45-69, 2001. 
Dados Internacionais de Catalogação na Publicação (CIP) DIVISĀO DE BIBLIOTECA E DOCUMENTAÇĀO - ESALQ/USP

\section{Berger, Irving Joseph}

Transformação de genomas plastidias de tomate e fumo visando a modificação do metabolismo de tocoferóis / Irving Joseph Berger. - - Piracicaba, 2005.

70 p. : il.

Tese (doutorado) - - Escola Superior de Agricultura Luiz de Queiroz, 2005.

Bibliografia.

1. Biologia molecular vegetal 2. Cloroplasto vegetal 3. Fumo 4. Genoma

5. Plastídeo 6. Tomate 7. Transformação genética 8. Vitamina E I. Título

CDD 635.642

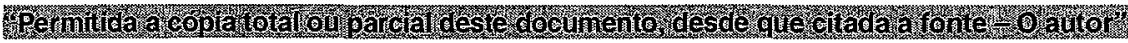




\begin{abstract}
À memória sempre presente de meu querido avô Ladislav Berger, incentivador maior de meus sonhos e crescimento profissional, idealizador de minha felicidade e sucesso,
\end{abstract}

\title{
DEDICO
}

Senhor, Pai celestial de infinita bondade, guarda-o ao Seu lado.

O que seria de nós, pobres almas em expiação Terrena, se não fossem os obstáculos que nos surpreendem a cada dia moldando de forma graciosa e por vezes até dolorosa nossa evolução espirituah, pessoale profissionah..

Irving J. Berger 


\section{AGRADECIMENTOS}

Agradeço a todos que de alguma forma colaboraram para o desenvolvimento do presente trabalho, em especial:

Ao Prof. Ricardo Antunes de Azevedo, orientador e motivador para a realização e viabilização do projeto;

À Profa. Helaine Carrer, pela orientação no trabalho, apoio pessoal e incentivo ao crescimento profissional e emocional;

Ao Prof. Ralph Bock, idealizador e co-orientador do projeto, pelos ensinamentos pessoais e técnicos, desafios e constante motivação;

Às agências de fomento que viabilizaram o projeto: a Coordenadoria de Aperfeiçoamento de Pessoal de Nível Superior (CAPES) e a Fundação de Apoio à Pesquisa do Estado de São Paulo (FAPESP);

Aos Departamentos de Genética e Ciências Biológicas da Escola Superior de Agricultura "Luiz de Queiroz" (ESALQ/USP) que disponibilizaram sua estrutura pessoal, técnica e laboratorial; 


\section{SUMÁRIO}

Página

LISTA DE FIGURAS ............................................................................... viii

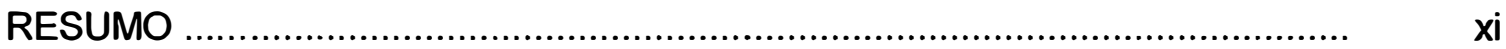

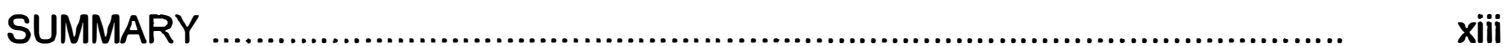

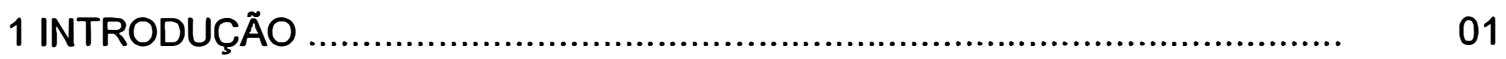

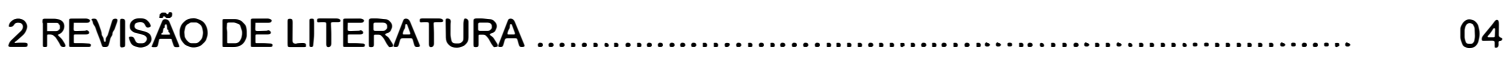

2.1 Tocoferóis: estrutura e funções ......................................................... 04

2.2 Biossintese de tocoferóis em plantas ................................................. 06

2.3 Modificação genética da biossíntese de tocoferóis ................................. 10

2.4 Transformação de genomas plastidiais em plantas superiores e tendências .............................................................................................. 13

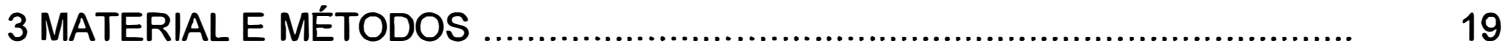

4 RESULTADOS E DISCUSSÃO .................................................... 27

4.1 Isolamento dos genes s/r0089 e s/r0090 de Synechocystis sp.

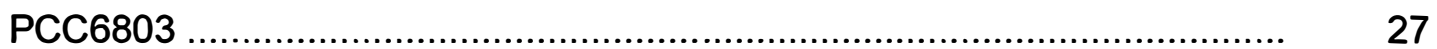

4.2 Construção dos vetores de transformação plJB30, plJB31 e plJB32 …....... 28

4.3 Seqüenciamento e confirmação das regiões codificadoras clonadas .......... 31

4.4 Bombardeamento de explantes foliares de tomate e fumo para transformação de cloroplastos ......................................................... 31

4.5 Conformação da transformação por teste de dupla seleção ...................... 33

4.6 Análises iniciais de homoplasmia: análise de progênie em fumo e Southern blot em tomate ....................................................................... $\quad 36$

4.7 Análise fenotípica em fumo ......................................................... $\quad 39$

4.8 Confirmação da integração dos genes de interesse e reconfirmação da homoplasmia 
4.9 Condução dos transformantes de tomate e produção de frutos

4.10 Seleção de métodos de detecção e separação de tocoferóis por

HPLC

4.11 Ensaio preliminar de resistência ao herbicida isoxaflutole 49

5 DISCUSSÃO FINAL 55

6 CONCLUSÕES 58

REFERÊNCIAS BIBLIOGRÁFICAS . 60 


\section{LISTA DE FIGURAS}

Página

1 Estrutura variável dos tocoferóis. Notar que a única diferença entre $\alpha$-e $\gamma$-tocoferol é que $\gamma$-tocoferol não é metilado na posição $5\left(R_{1}\right)$ do anel aromático. Adaptado de Hensley et al. (2004)

2 Via biossintética de tocoferóis em plastídeos de plantas. Setas horizontais pretas indicam as primeiras enzimas clonadas e caracterizadas da via. Fonte: Hirschberg (1999)

3 Regiões codificadoras dos genes s/r de Synechocystis PCC6803 amplificadas via PCR e separadas em gel de agarose $1 \%$ corado com brometo de etídio. 1. 1Kb DNA Plus Ladder; 2. s/r0089; 3.

s/r0090; 4. s/r0089 + s/r0090.

4 Vetores de transformação de cloroplastos via recombinação homóloga plJB30, plJB31 e plJB32. Substituição da região codificadora do gene nptll pelos genes slr. Em todas as construções os genes s/r encontram-se sob controle da expressão pelo promotor Tatpl e terminalizador Prps14

5 Análise de restrição dos clones obtidos e selecionados para as construções plJB30, plJB31 e plJB32. Os plasmídeos foram digeridos com as enzimas de restrição Xbal e $\mathrm{Ncol}$ e separados em gel de agarose 1\%. 1. 1kb DNA Ladder; 2. plJB30; 3. plJB31; 4. plJB32

6 Transformantes primários de fumo obtidos 4 semanas após o primeiro experimento de bombardeamento para as construções plJB30 e plJB31

7 Transformantes primários de tomate para a construção plJB32. 
IPA-6 à esquerda e Santa Clara à direita

8 Plantas transplastômicas de fumo da construção plJB30 transferidas para meio RMOP contendo os antibióticos espectinomicina e estreptomicina ( $500 \mu \mathrm{g} / \mathrm{ml}$ cada). Plantas que apresentam crescimento são confirmadas como transformadas

9 Análise de progênie de plantas transplastômicas de fumo. A: sementes germinadas de plantas homoplásmica, todas as plântulas apresentam-se resistentes à espectinomicina, mostrando fenótipo normal de coloração verde. B. sementes germinadas de plantas heteroplásmica, caracterizada por segregação traduzida na presença de plântulas resistentes normais e plântulas albinas como resultado de inibição da tradução cloroplastidial

10 Plantas transplastômicas de tomate IPA-6 para a construção plJB32 transferidas para substrato comercial para aclimatação e desenvolvimento em câmara de crescimento sob condições controladas

11 Análise de RFLP e Southern blot de plantas transplastômicas de tomate IPA-6 para a construção plJB32. 1 a 10: plantas transplastômicas plJB32/1 A, B, C, D, E, F, G, H, I e J respectivamente; 11: planta não-transformada da cultivar IPA-6

12 Plantas de fumo cultivadas em câmara de crescimento sob condições de baixa intensidade luminosa $\left(60 \mu\right.$ moles $\left./ \mathrm{m}^{2}\right)$. 1: controle, planta não transformada; 2: plantas homoplásmicas para a contrução plJB30; 3: plantas homoplásmicas para a construção pIJB31; 4: plantas homoplásmicas para a construção pIJB32.

13 Plantas de fumo cultivadas em câmara de crescimento sob condições de intensidade luminosa normal $\left(200 \mu\right.$ moles $\left./ \mathrm{m}^{2}\right)$. 1: controle, planta não transformada; 2: plantas homoplásmicas para a contrução plJB30; 3: plantas homoplásmicas para a construção plJB31; 4: plantas homoplásmicas para a construção plJB32.

14 Plantas de fumo cultivadas em câmara de crescimento sob condições de alta intensidade luminosa $\left(400 \mu \mathrm{moles} / \mathrm{m}^{2}\right)$. 1: 
controle, planta não transformada; 2: planta homoplásmicas para a contrução plJB30; 3: plantas homoplásmicas para a construção plJB31; 4: plantas homoplásmicas para a construção plJB32

15 Análise de homoplasmia das plantas transplastômicas de tomate e fumo estudadas através de RFLP e Southern blot. Fragmentos de plastomas não tranformados (controles): $4 \mathrm{~kb}$; Fragmentos de plastomas transformados com um dos genes de interesse, s/r0089 ou slr0090: 7,2 kb; Fragmentos de plastomas transformados com os dois genes de interesse s/r0089 e slr0090: 8,3 kb

16 Análise da integração dos genes s/r0089 e s/10090 nas plantas transplastômicas de tomate e fumo por RFLP e Southern blot. Fragmentos de plastomas transformados com um dos genes de interesse, s/r0089 ou s/r0090: 7,2 kb; Fragmentos de plastomas transformados com os dois genes de interesse s/r0089 e s/r0090: $8,3 \mathrm{~kb}$

17 Frutos da primeira coleta em plantas transplastômicas de tomate para a construção plJB32 contendo os genes s/r0089 e s/r0090 de Synechocystis sp. PCC6903

18 Primeira plântula obtida através da germinação de semente F1 da linha transplastômica de tomate plJB32/G em meio RM contendo espectinomicina $(100 \mu \mathrm{g} / \mathrm{ml})$

19 Teste de resistência ao herbicida isoxaflutole $(0,6 \mathrm{ppm}) \mathrm{em}$ germinação. A: fumo não transformado; $B$ : linha transplastômica plJB30\#23B; C: linha transplastômica plJB31\#03A; D: linha transplastômica plJB32\#14B

20 Teste de germinação de linha controle e da linha transplastômica pIJB31A em MS contendo 0, 0,5, 1 e 2 ppm de isoxaflutole, ingrediente ativo (Provence 750WG, 75\% i.a., Bayer CropScience). Concentrações superiores a 8 ppm, equivalentes a 16, 32 e 64 ppm não são mostradas por terem gerado exclusivamente plântulas albinas e com desenvolvimento comprometido 


\title{
TRANSFORMAÇÃO DE GENOMAS PLASTIDIAIS DE TOMATE E FUMO VISANDO A MODIFICAÇÃO DO METABOLISMO DE TOCOFERÓIS
}

\author{
Autor: IRVING JOSEPH BERGER
}

Orientador: Prof. Dr. RICARDO ANTUNES DE AZEVEDO

\section{RESUMO}

A transformação de genomas cloroplastidiais de tomate (Lycopersicon esculentum Mild.) no ano de 2001, mais de uma década após o primeiro resultado do desenvolvimento dessa tecnologia em fumo, ampliou a oportunidade para a introdução e expressão de transgenes em genomas plastidiais de plantas de valor alimentício. Dentre outras vantagens, a segurança ambiental e os altos níveis de expressão de transgenes, com conseqüente elevado acúmulo da proteína de interesse, são decorrentes da transformação de genomas cloroplastidiais. Uma vez que plastídeos estão envolvidos em diversos processos metabólicos celulares, a modificação de qualquer um desses processos pode ser viabilizada pela introdução de genes exógenos ou alteração de genes endógenos em plastídeos. Dadas as importantes propriedades terapêuticas associadas ao consumo de vitamina $E$, especialmente $\alpha$-tocoferol, em doses superiores àquelas necessárias à nutrição humana (100 a $400 \mathrm{IU})$, este trabalho teve como objetivo a obtenção de plantas com alto conteúdo desta vitamina pela transformação de cloroplastos. Os genes s/r0089 e s/r0090 de Synechocystis sp. 
PCC6803, que codificam as enzimas $\gamma$-tocoferol metil transferase $(\gamma$-TMT) e HPP dioxigenase (HPPDase) respectivamente, foram isolados e introduzidos em vetores de transformação de cloroplastos, resultando nos plasmídeos pIJB30, plJB31 e plJB32, os quais contêm as regiões codificadoras dos genes s/r0089, s/r0090 e s/r0089+s/r0090, respectivamente. Experimentos de biobalística em explantes foliares de tomate e fumo foram conduzidos para a integração e expressão dos transgenes nos genomas plastidiais. Plantas de fumo contendo as três construções foram confirmadas serem homoplásmicas, possuindo os transgenes corretamente integrados. Desde que superexpressão de genes que codificam a enzima HPPDase em plantas podem levar à resistência aos herbicidas inibidores desta enzima, plantas transplastômicas de fumo foram analisadas e apresentaram resistência ao isoxaflutole em testes in vitro. Plantas de tomate homoplásmicas contendo os transgenes foram confirmadas somente para a construção plJB32, apresentando os trangenes corretamente integrados. 


\title{
TOMATO AND TOBACCO PLASTID GENOME TRANSFORMATION FOR ENGINEERING OF THE TOCOPHEROL METABOLISM
}

\author{
Author: IRVING JOSEPH BERGER \\ Adviser: Prof. Dr. RICARDO ANTUNES DE AZEVEDO
}

\section{SUMMARY}

Tomato (Lycopersicon esculentum Mild.) chloroplast transformation in 2001, more than one decade after the first results from the transplastomic technology in tobacco, has increased the opportunity to the introduction and expression of transgenes into plastid genomes of crop species. Among other advantages, environmental safety and high levels of transgene expression with consequent great accumulation of the introduced recombinant protein are results of the plastid transformation. Plastids take part in several metabolic cellular processes and so modification of any of the involved pathways could be viable by the introduction of exogenous genes or alteration of endogenous genes in chloroplast genomes. Since vitamin $E$, specially $\alpha$-tocopherol, has important therapeutic properties when daily intakes exceed normal nutritional requirements (100 to $400 \mathrm{IU}$ ), the goal of this work was the production of vitamin $\mathrm{E}$ rich plants by chloroplast transformation. In that way, the Synechocystis sp. PCC6803 s/r0089 and s/r0090 genes coding for the $\gamma$ tocopherol methyl transferase ( $\gamma$-TMT) and HPP dioxygenase (HPPDase) enzymes 
respectively were isolated and introduced in chloroplast transformation vectors resulting in the plJB30, plJB31 and plJB32 plasmids, which contain the s/r0089, s/r0090 and s/r0089+s/r0090 coding regions respectively. Biolistic experiments with tomato and tobacco leaf explants were performed for the integration and expression of the constructs into the plastid genomes. Transformed tobacco plants containing all the three constructs were confirmed to be homoplasmic and have the transgenes correctly integrated. Since overexpression of the HPPDase coding genes in plants can lead to resistance against HPPD inhibiting herbicides, transplatomic tobacco plants were analized and have shown resistance against isoxaflutole on in vitro tests. Tomato homoplasmic plants containing the transgenes were confirmed only for the plJB32 construct and have also the transgenes correctly integrated. 


\section{INTRODUÇÃO}

O desenvolvimento de tecnologias de alteração genética do genoma de plastídeos de Chlamydomonas reinhardtii (Boyton et al., 1988) e Nicotiana tabacum (Svab et al., 1990) e, em especial, sua expansão para as culturas de batata (Sidorov et al, 1999) e de tomate (Ruf et al., 2001), demonstraram o potencial desta tecnologia para a introdução e expressão de transgenes em genomas plastidiais de plantas cultivadas pela transformação de cloroplastos. Dentre outras vantagens, a segurança ambiental e os altos niveis de expressão de transgenes com conseqüente elevado acúmulo da proteína de interesse são decorrentes da transformação de genomas plastidiais (revisado em Bock \& Hagemann, 2000; Maliga, 2004).

Em plantas de fumo, modelo único entre vegetais superiores explorado até a transformação de batata e tomate, diversos estudos foram realizados em esforços de desenvolvimento de um sistema eficiente e seguro de expressão de genes heterólogos em plantas. Nesse contexto, plantas de fumo transplastômicas (com genoma plastidial alterado) mostraram ser de grande utilidade para a produção de proteínas de interesse farmacêutico por produzirem substâncias diversas tais quais vacinas, anticorpos e compostos derivados do metabolismo secundário vegetal, assim como um hormônio de crescimento humano, a somatotropina, (Daniell et al, 2002; Maliga, 2003; Bock \& Khan, 2004). Da mesma forma, a tecnologia tem sido considerada de grande potencial para a expressão e modificação de características de interesse agronômico, incluindo resistência a herbicidas e insetos (revisado em Daniell et 
al., 2005). Em adição, a literatura mostra claramente o potencial da aplicação da tecnologia de transformação de cloroplastos na modificação metabólica de vias compartimentalizadas em plastídeos (revisado em Bock \& Khan, 2004). Plastídeos estão envolvidos em diversos processos metabólicos celulares, tais como fotossintese, assimilação do nitrogênio e enxofre, metabolismo de aminoácidos, lipídeos, tocoferóis, carotenóides e clorofilas. A modificação de qualquer desses processos, para o redirecionamento ou potencialização das rotas metabólicas envolvidas nesses diversos processos, pode ser viabilizada pela introdução de genes exógenos ou alteração de genes endógenos em plastídeos.

Dadas as importantes propriedades terapêuticas associadas ao consumo de vitamina $E$ ( $\alpha$-tocoferol) em doses 10 a 100 vezes superiores àquelas necessárias à nutrição humana (Traber \& Sies, 1996), o controle do metabolismo de tocoferóis representa alvo de interesse e com potencial para modificação via transformação de cloroplastos. Com esse objetivo, o presente trabalho visa a introdução e expressão dos genes slr0089 e s/r0090 de Synechocystis sp. PCC6803 em genomas plastidiais de tomate e fumo via transformação do genoma plastidial, buscando a superexpressão das enzimas $\gamma$-tocoferol metil transferase ( $\gamma$-TMT) e HPP dioxigenase (HPPDase), respectivamente, com esperado aumento do nivel de vitamina $E$ (especialmente $\alpha$-tocoferol) em diferentes tecidos de tomate e fumo. $O$ sucesso no aumento do teor de $\alpha$-tocoferol em frutos de tomate representará a disponibilização de uma fonte relativamente barata e de pronto consumo de vitamina $E$ para a população, como também, a concretização do primeiro sistema de superexpressão de proteínas de interesse em órgão comestivel decorrente da tecnologia de transformação de cloroplastos. Uma vez já obtidas no presente trabalho, plantas de tomate e fumo expressando os genes que codificam as enzimas $\gamma$-tocoferol metil transferase $(\gamma$-TMT) e HPP dioxigenase (HPPDase) separadamente e na forma de operon, análises bioquímicas 
baseadas em HPLC serão suficientes para comprovar a eficácia da estratégia utilizada no aumento do teor de tocoferóis, em especial $\alpha$-tocoferol, nestas espécies. Em adição, a enzima HPPDase, codificada pelo gene slr0090, é alvo de um grupo de herbicidas bastante promissor da indústria química, que compreende moléculas tais quais o isoxaflutole e o mesotrione (Lee et al., 1998). Teste preliminar de resistência ao isoxaflutole, em germinação in vitro, mostrou o potencial de plantas de fumo expressando este gene em tolerar niveis do herbicida superiores àqueles tolerados por plantas não transformadas. Estudos mais aprofundados, incluindo a aplicação em pósemergência dos herbicidas isoxaflutole e mesotrione em plantas conduzidas em vasos, podem vir a identificar importante estratégia para obtenção de plantas resistentes a essa classe de herbicidas. Plantas resistentes à herbicidas apresentam grande interesse econômico em espécies cultivadas. Resultam em vantagem competitiva no manejo de plantas daninhas e reduzem o custo de produção. 


\section{REVISÃO DE LITERATURA}

\subsection{Tocoferóis: estrutura e funções}

Tocoferóis, antioxidantes lipossolúveis conhecidos em conjunto aos tocotrienóis como vitamina $\mathrm{E}$, representam um grupo de compostos produzidos exclusivamente por organismos fotossintetizantes. Os quatro tocoferóis de ocorrência natural, $\alpha-, \beta-, \gamma$-e $\delta$-tocoferol (Figura 1 ) diferem somente no número e posição de radicais metil no anel aromático (Hirschberg, 1999) e na atividade antioxidante in vivo (Fukuzawa et al., 1982). A forma natural de $\alpha$-tocoferol ocorre como um único isômero $(R, R, R)$ - $\alpha$-tocoferol, enquanto o $\alpha$-tocoferol sintético (normalmente utilizado em suplementos de vitamina $E$ ) é uma mistura racêmica de oito diferentes isômeros (Hirschberg, 1999). A maioria desses isômeros é menos eficaz que o isômero natural (Traber \& Sies, 1996) e, portanto, a disponibilização de fontes de fácil acesso do isômero natural seria de grande importância para a nutrição humana.

$\mathrm{O} \alpha$-tocoferol é considerado tradicionalmente a forma mais efetiva entre os tocoferóis como vitamina $\mathrm{E}$, apresentando atividade biológica cerca de 10 vezes maior do que aquela de seu precursor biossintético imediato $\gamma$ tocoferol (Hirschberg, 1999). Nesse aspecto, a atividade biológica do $\alpha$ tocoferol e seus análogos tem sido extensivamente estudada nos últimos 10 a 15 anos para elucidar as diferenças marcantes e opostas em atividade in vivo e in vitro normalmente relatadas. A absorção e distribuição preferencial de $\alpha$ tocoferol no organismo animal, em detrimento de seus análogos, têm sido 
apontadas e mostradas ocorrer em função da atividade de duas enzimas: a proteína de ligação ao tocoferol (TBP, tocopherol binding protein) e a proteína de transferência do $\alpha$-tocoferol ( $\alpha$ TTP - tocopherol transfer protein), ambas de origem hepática (Sato et al., 1991; Kaempf-Rotzoll, 2003). Em 1997, Hosomi e colaboradores propuseram a afinidade dos diversos análogos da vitamina $E$ pela $\alpha$ TTP, que por sua vez determina seus níveis plasmáticos, como o principal determinante de suas atividades biológicas. Plotando seus dados contra resultados de testes típicos em ratos de determinação da atividade biológica para os diversos análogos da vitamina E, Hosomi et al. (1997) encontraram relação linear $\left(r^{2}=0,964\right)$ entre afinidade relativa à $\alpha$ TTP e atividade biológica. Tais dados corroboraram a relação direta que Catignani \& Bieri ${ }^{1}$ citados por Hosomi et al. (1997) relataram, já em 1977, entre a atividade biológica de diversas formas de vitamina $\mathrm{E}$ e sua habilidade em competir por ligação à proteína de ligação ao tocoferol (TBP).

Embora os níveis mínimos de vitamina $E$ recomendados (10 a 13,4 $\mathrm{UI}$ - unidades internacionais, NRC, 1989) sejam normalmente alcançados em dietas médias contendo vegetais, ingestão diária de excessos de vitamina $E$, da ordem de 100 a $1000 \mathrm{UI}$, correspondendo a cerca de até $1000 \mathrm{mg}$ de $(R, R, R)$ $\alpha$-tocoferol, foi mostrada estar associada com redução de risco de doenças cardiovasculares, algumas formas de câncer, melhoria da função imunológica, redução da velocidade de progresso de numerosas condições degenerativas associadas à idade, tais como catarata, artrite e desordens do sistema nervoso causadas por danos acumulativos mediados por espécies reativas de oxigênio nos mais diversos tecidos (Traber \& Sies, 1996). Em estudos realizados entre 1993 e 2004 com 136 mil pessoas, Edgard Miller, professor da Faculdade de Medicina da Universidade John Hopkins, de Baltimore (Maryland), concluiu que ingestão diária igual ou superior a $400 \mathrm{UI}$ de vitamina E sintética pode levar a maiores riscos de morte, o que não ocorre com ingestão limitada a $200 \mathrm{UI}$ (270

\footnotetext{
${ }^{1}$ Catignani, G.L.; Bieri, J.G. Biochim. Biophys. Acta, v.497, p.349-357, 1977.
} 
$\mathrm{mg}$ ). Segundo afirma o pesquisador, especialistas dizem que tais oxidantes parecem benéficos apenas na alimentação (e não suplementação artificial) e que pessoas que ingerem alimentos ricos em vitaminas realmente correm menos riscos de problemas cardíacos, por exemplo (http://www1.folha.uol.com.br/folha/ ciencia/ult306u12639.shtml).

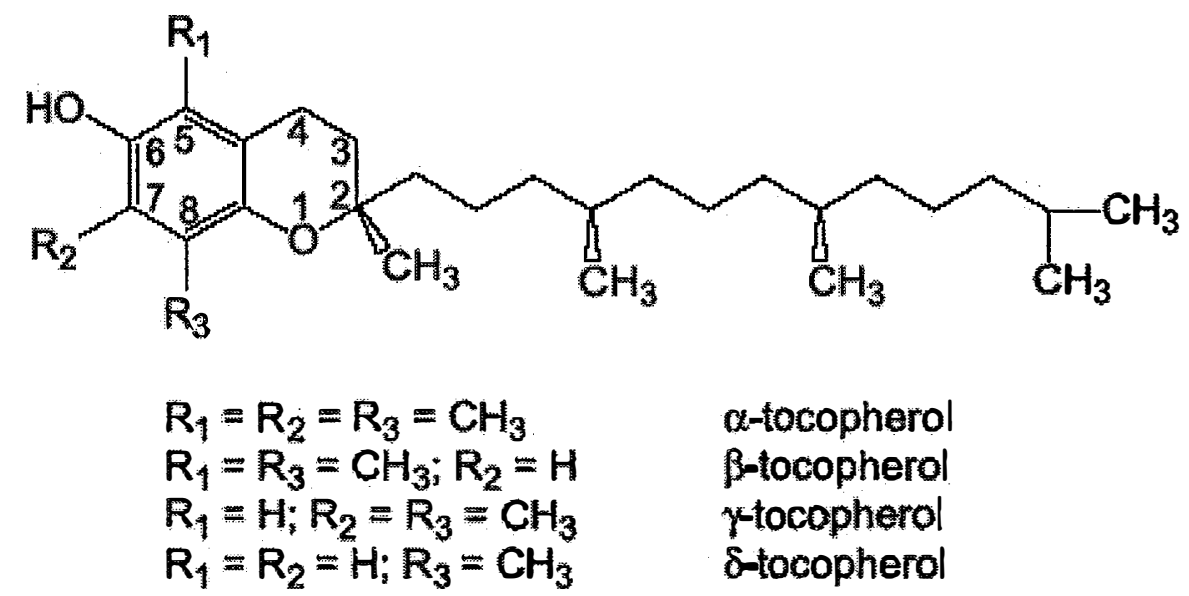

Figura 1 - Estrutura variável dos tocoferóis. Notar que a única diferença entre $\alpha$ e $\gamma$-tocoferol é que $\gamma$-tocoferol não é metilado na posição $5\left(R_{1}\right)$ do anel aromático. Adaptado de Hensley et al. (2004)

\subsection{Biossíntese de tocoferóis em plantas}

A via biossintética de tocoferóis em plantas (Figura 2), incluindo a biossíntese de $\alpha-, \beta-, \gamma$ - e $\delta$-tocoferóis, foi elucidada há três décadas por meio de experimentos bioquímicos clássicos (Whistance \& Threlfall, 1970). Os tocoferóis são sintetizados através de precursores comuns a duas vias: a via dos isoprenóides (também responsável pela biossíntese de carotenóides), contribuindo com a cauda hidrofóbica típica de tocoferóis, e a via de biossíntese do ácido homogentísico, responsável pela doação do grupo funcional dos tocoferóis, constituído por um anel aromático (Hirschberg, 1999). 
Os tocoferóis tratam-se, desta forma, de compostos secundários derivados da via plastidial dos isoprenóides em plantas, conjuntamente com carotenóides, plastoquinonas e outras quinonas, ácido abscísico e diversos outros compostos.

Nos anos de 1997 e 1998 foram relatados os primeiros esforços de sucesso na clonagem e caracterização de genes envolvidos na via biossintética de tocoferóis em plantas e cianobactérias. Genes codificando a enzima 4hidroxifenil piruvato dioxigenase (HPPDase) foram inicialmente clonados de cenoura (Garcia et al., 1997), cevada (Kleber-Janke \& Krupinska, 1997) e Arabidopsis thaliana (Norris et al., 1998). A enzima supre a via com os grupos funcionais (anéis aromáticos) para o acoplamento das caudas hidrofóbicas, formando quinonas precursoras dos tocoferóis. Em adição, Shintani \& DellaPenna (1998) clonaram e caracterizaram a enzima $\gamma$-tocoferol metil transferase $(\gamma$-TMT) de $A$. thaliana e Synechocystis sp PCC6803. A enzima promove a metilação final de $\gamma$-tocoferol para gerar o produto final da via, $0 \alpha$ tocoferol (Figura 2).

A partir do ano de 2002 , todos os genes da via dos tocoferóis foram isolados de Arabidopsis thaliana, alguns também da cianobactéria Synechocystis sp. PCC6803, e caracterizados, confirmando a via metabólica hipotetizada pelos ensaios bioquímicos (revisado em Ajjawi \& Shintani, 2004).

Devido a sua importância para a agricultura, nutrição e significância terapêutica, a enzima 4-hidroxifenil piruvato dioxigenase (HPPD) tem sido largamente estudada e caracterizada (revisado em Moran, 2005). Segundo destaca Moran (2005), a enzima HPPD é uma oxigenase Fe(II)-dependente que cataliza a conversão de hidroxifenil piruvato em homogentisato (ácido homogentísico). A reação envolve descarboxilação, migração substitutiva e oxigenação aromática em um único ciclo catalítico. A enzima HPPD catalisa o segundo passo da via do catabolismo de tirosina, que é comum a essencialmente todas as formas de vida aeróbicas. Em plantas a via possui uma ramificação anabólica no homogentisato que produz cofatores redox 
derivados de isoprenóides tais quais a plastoquinona e os tocoferóis, conforme já citado anteriormente. Ainda, segundo Moran (2005), molécula multicetônicas de ocorrência natural atuam como agentes alelopáticos na inibição da HPPD e impedem a produção de homogentisato e seus derivados requeridos como cofatores. O importante é que esse mecanismo vem sendo justamente utilizado como base para o desenvolvimento de uma gama de moléculas herbicidas efetivas rotineiramente utilizadas comercialmente. De fato, a estratégia de inibição da HPPD tem sido usada como modo de ação promissor para herbicidas da classe das tricetonas pela indústria de pesticidas desde 1982 (Lee et al., 1998). Inibição da enzima bloqueia indiretamente a síntese de carotenóides e resulta em conseqüente degradação de clorofilas e fenótipo albino em folhas (Meazza et al., 2002). Dois ingredientes ativos usualmente utilizados nas culturas de milho e cana-de-açúcar são representados pelo isoxaflutole (Provence 750WG, Bayer CropScience) e o mesotrione (Callisto, Syngenta), normalmente aplicados em pré e pós emergência respectivamente (Christofoletti, 2005, comunicação pessoal). 


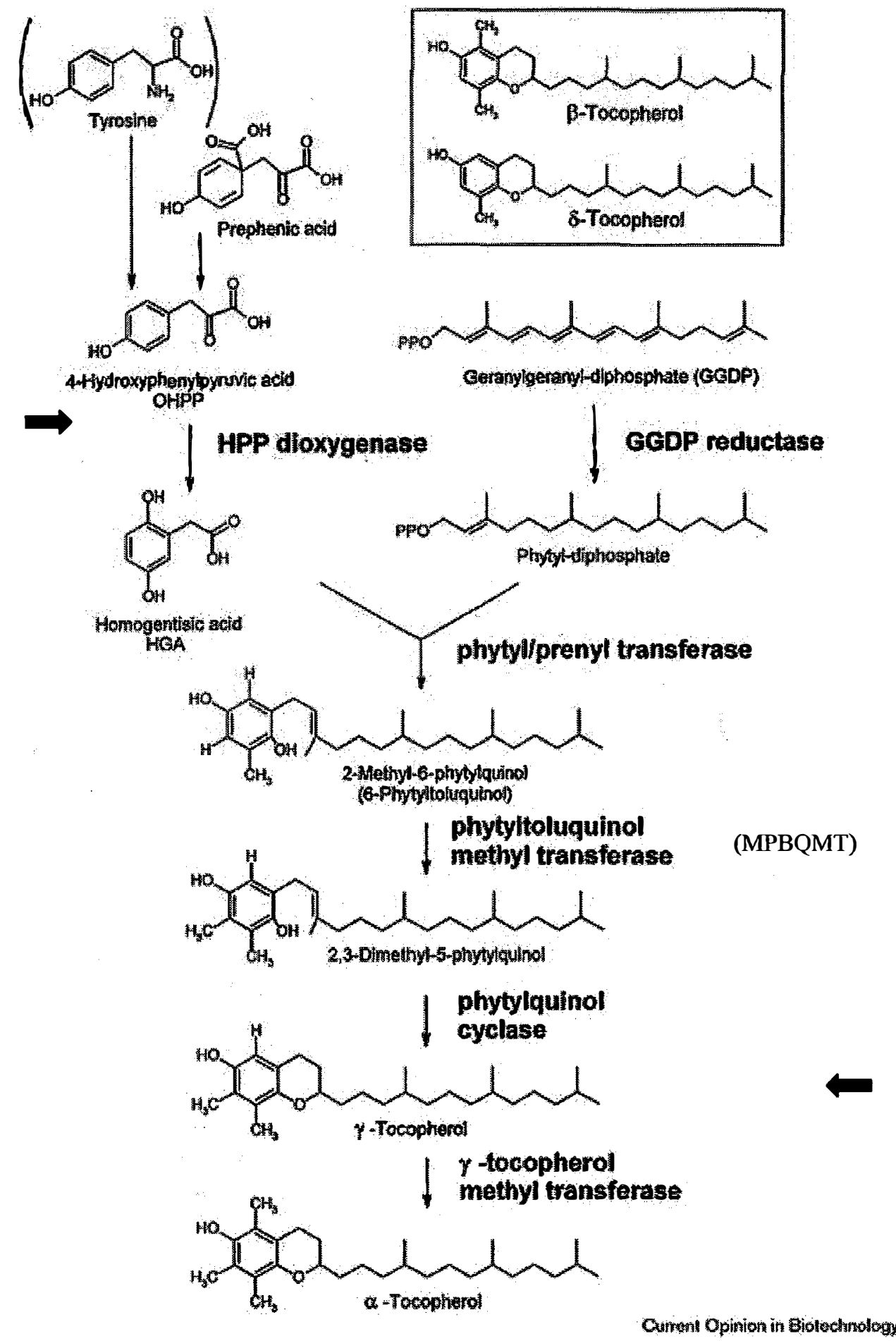

Figura 2 - Via biossintética de tocoferóis em plastídeos de plantas. Setas horizontais pretas indicam as primeiras enzimas clonadas e caracterizadas da via. Fonte: Hirschberg (1999) 
A enzima $\gamma$-tocoferol metil transferase $(\gamma$-TMT), por sua vez, tem papel exclusivo na síntese de tocoferóis e vêm sendo talvez por esse motivo estudada em ritmos mais lentos. Koch et al. (2003), em adição ao trabalho realizado por Shintani \& DellaPenna (1998) e um esquema de purificação proposto inicialmente por D'Harlingue \& Camara (1985), realizaram uma caracterização bioquímica detalhada das enzimas $\gamma$-TMT de Arabidospis thaliana e de frutos de Capsicum annuum $L$, tecido que acumula altos teores de tocoferóis. Tratou-se do primeiro esforço em caracterizar minúcias das propriedades enzimáticas de $\gamma$-TMTs de plantas superiores. As enzimas apresentaram características bioquímicas bastante similares, incluindo a especificidade a substratos. Ambas convertem $\delta$ - e $\gamma$ - em $\beta$ - e $\alpha$-tocoferóis, respectivamente, mas não aceitam $\beta$-tocoferol como substrato, apontando para uma metilação específica da enzima no carbono 5 do anel aromático de tocoferóis. Devido a uma maior especificidade da enzima de Arabidopsis por $\delta$ tocoferol em relação a $\gamma$-tocoferol, os autores concluem que seus resultados enfatizam o papel da $\gamma$-TMT em regular o espectro de tocoferóis acumulados nas plantas.

\subsection{Modificação genética da biossíntese de tocoferóis}

Avanço importante no engenheiramento metabólico de tocoferóis foi relatado inicialmente por Shintani \& DellaPenna (1998) com a clonagem e caracterização do cDNA da enzima $\gamma$-tocoferol metil transferase $(\gamma$-TMT) de Arabidopsis thaliana. Superexpressão da $\gamma$-TMT em sementes transgênicas de Arabidopsis foi realizada pelo uso do promotor específico de sementes DC3 de cenoura. Enquanto $97 \%$ do total de tocoferóis em sementes selvagens de Arabidopsis são representados por $\gamma$-tocoferol, sementes transgênicas apresentaram $85-95 \%$ de $\alpha$-tocoferol, representando um aumento superior a 80 
vezes o teor de $\alpha$-tocoferol quando em comparação a sementes controle não alteradas. De forma interessante, os niveis totais de tocoferóis não foram alterados nas plantas transgênicas, indicando ausência de um mecanismo de regulação por 'feed-back' na via de síntese em sementes ou que $\alpha$-tocoferol pode atuar nesse mecanismo da mesma forma que o $\gamma$-tocoferol (Hirschberg, 1999). Acima de tudo, o experimento demonstrou a potencial elevação do nível de vitamina $E$ funcional (leia-se $\alpha$-tocoferol) em tecidos vegetais por manipulação genética relativamente simples, envolvendo somente a introdução de um gene e a conseqüente conversão de $\gamma$-tocoferol em $\alpha$-tocoferol, passo que deve ser controlado na via metabólica em sementes (Shintani \& DellaPenna, 1998). Esse substancial aumento no conteúdo de $\alpha$-tocoferol (da ordem de 80 vezes) em tecidos vegetais comestiveis, tal como frutos de tomate e outras culturas, permitiria disponibilizar ao consumidor em geral fontes e dosagens suficientes de vitamina $E$ para atender as exigências terapêuticas já mencionadas.

Esforços sucessivos na modificação da biossíntese de tocoferóis em plantas só foram relatados alguns anos depois por Tsegaye et al. (2002) e Falk et al. (2003) que superexpressaram o gene HPPD de Arabidopsis em sementes e folhas de Arabidopsis e fumo para testar a hipótese de que a atividade da enzima pudesse representar passo regulatório limitante da via dos tocoferóis. Embora as plantas transformadas tenham mostrado aumentos expressivos na atividade enzimática quando comparadas a plantas controle, somente pequenos aumentos no conteúdo de tocoferóis foram encontrados (10\% em folhas e $30 \%$ em sementes), sugerindo a princípio que a enzima HPPD por si só não seria suficiente para aumentar consideravelmente o fluxo biossintético da via dos tocoferóis. Em oposição às conclusões dos autores, pode-se imaginar que níveis de expressão mais elevados poderiam conduzir a também maiores aumentos no conteúdo de tocoferóis, embora não tenha sido 
caracterizada uma proporcionalidade da atividade enzimática com o aumento de fluxo da via nos experimentos expostos.

$\mathrm{Na}$ seqüência e ainda com início no ano de 2002, outros genes da via de biossíntese de tocoferóis em plantas foram isolados de Arabidopsis thaliana (e muitas vezes seus análogos em Synechocystis sp. PCC6803) e caracterizados. Superexpressão desses genes em Arabidopsis ou fumo geraram um perfil exato de quais genes e seus produtos estão diretamente envolvidos no aspecto qualitativo ou quantitativo na via (revisado em Ajjawi \& Shintani, 2004). Vários grupos de pesquisa passaram a utilizar tais informações e vêm investindo em esforços de transferência desse conhecimento para espécies de interesse alimentício, onde a conseqüente geração de produtos é desejada. No ano de 2003, Van Eenennaam e colaboradores (Van Eenennaam et al., 2003) superexpressaram as enzimas $\gamma$-TMT e fitiltoluquinol metil transferase (MPBQMT, ver Figura 2) de Arabidopsis em soja. Como resultado, 95\% do conteúdo em $\gamma$-tocoferol, normalmente acumulado em soja-grão foi convertido em $\alpha$-tocoferol, gerando um aumento real de 5 vezes na atividade de vitamina E. Da mesma forma, Cho et al. (2005), superexpressaram o mesmo cDNA que codifica a $\gamma$-TMT de Arabidopsis em plantas de alface (Lactuca sativa L.) e obtiveram uma quase completa conversão do conteúdo original de $\gamma$ - em $\alpha$-tocoferol. Em alface essa conversão representa um aumento superior a 2 vezes a atividade de vitamina $E$ por unidade de peso fresco de folhas de alface. Ambos os trabalhos resultaram em material genético que indica a possibilidade de uso prático da tecnologia no melhoramento vegetal e desenvolvimento de variedades enriquecidas em vitamina $E$.

Para condução de novos experimentos de modificação do metabolismo de tocoferóis, considerando as potencialidades e possibilidades de uso da transformação de cloroplastos, as enzimas $\gamma$-TMT e HPPDase nativas da cianobactéria Synechocystis sp. PCC6803 já caracterizadas, podem ser consideradas. As enzimas são codificadas por genes localizados em um 
operon constituído de 10 genes compreendido entre as bases 2.893.184 e 2.905.235 de seu genoma (GenBank, acession \# NC000911), correspondendo às ORFs slr0089 (2.896.657 a 2.897.610) e slr0090 (2.897.634 a 2.898.653) respectivamente (Shintani \& DellaPenna, 1998). Isolamento e construção de vetores de transformação de cloroplastos contendo tais genes tipicamente procarióticos e relacionados evolutivamente aos genes plastidiais (uma vez que plastídeos originaram-se de cianobactérias primitivas, Gray (1993)), devem resultar, após transformação, em expressão desses genes e modificação do metabolismo de tocoferóis em plantas de tomate e fumo, conforme expressão já demonstrada em Escherichia coli por Shintani \& DellaPenna (1998) ou Arabidopsis por Norris et al. (1998). Purificação da enzima $\gamma$-tocoferol metil transferase de cromoplastos de pimentão (d'Harlinghe \& Camara, 1985; Koch et al., 2003) mostrando que a via encontra-se também operante em frutos durante $o$ amadurecimento, gera expectativas para a possibilidade de alteração dos niveis de tocoferóis nesse órgão vegetal de interesse alimentício.

\subsection{Transformação de genomas plastidiais em plantas superiores e tendências}

Cloroplastos são os representantes mais abundantes de uma família de organelas de dupla membrana denominadas genericamente plastídeos e de comum ocorrência em células vegetais. Os plastídeos podem apresentar-se de várias formas, dentre elas os cloroplastos, tipicamente caracterizados por conter clorofila. Além de responsáveis pelo processo da fotossíntese, os plastídeos participam também da biossintese de aminoácidos, nucleotídeos, lipídios, tocoferóis, amido e estão diretamente envolvidos em uma gama de processos degradativos e sintetizadores no climatério de frutos, incluindo a degradação de clorofila na membrana dos tilacóides, a conversão de amido em reservas de açúcares e a síntese de pigmentos carotenóides. Essa intensa 
participação no metabolismo celular se deve provavelmente: (i) à necessidade de compartimentalização de determinadas vias metabólicas (resultado de todo um processo evolutivo) e (ii) ao fato de a coordenação de células vegetais durante seu desenvolvimento ser dependente de três sistemas genéticos distintos, porém interdependentes; além do núcleo, cloroplastos e mitocôndrias possuem seus próprios genomas.

O genoma típico de cloroplastos (plastoma) é circular, possui de 120 a $180 \mathrm{~kb}$ em plantas superiores, é idêntico em todos os tipos de plastídeos e possui uma região duplicada com orientação invertida de aproximadamente 25 kb (Maliga, 1993). Análise de seqüências completas de genomas cloroplastidiais permite concluir que esse DNA (ptDNA) contém cerca de 120130 genes, incluindo codificadores de rRNAs, tRNAs, genes envolvidos no metabolismo fotossintético, alguns peptídeos não identificados e regiões de provável codificação de polipeptídios (ORFs), Shinozaki et al. (1986) e Sugiura (1992).

O desenvolvimento da tecnologia de transformação de cloroplastos, com a disponibilização de métodos rotineiros de introdução e expressão de DNA exógeno em plastídeos de Nicotiana tabacum (Svab et al., 1990; Svab \& Maliga, 1993; Carrer et al., 1993; Koop et al., 1996 e muitos outros), a possibilidade de aplicações biotecnológicas (McBride et al., 1995; Kota et al., 1999; Staub et al., 2000) e a recente transformação dos genomas plastidiais de plantas de batata (Sidorov et al., 1999), tomate (Ruf et al., 2001), cenoura (Kumar et al., 2004a), soja (Dufourmantel et al., 2004) e algodão (Kumar et al.,2004b), abriram as portas para a introdução e expressão de transgenes de interesse em genomas plastidiais de plantas cultivadas.

Transformação estável de genomas cloroplastidiais tem sido realizada envolvendo: (i) introdução do DNA transformante (via biobalística ou polietilenoglicol) no ambiente cloroplastidial, (ii) integração estável do DNA transformante por dois eventos de recombinação homóloga, e (iii) eliminação seletiva de cópias originais do genoma plastidial com acúmulo do 
transplastoma (plastoma transformado) durante sucessivas divisões celulares em meio seletivo (Maliga et al., 1993; Bock \& Hagemann, 2000; Maliga 2004).

A obtenção de transformantes estáveis depende da integração, também estável, do DNA exógeno no plastoma. Sendo os cloroplastos um compartimento celular tipicamente procariótico, a integração do DNA transformante se dá por recombinação homóloga, mecanismo herdado pelos plastídeos de seus ancestrais procarióticos (Cerutti et al., 1992), e que foi mostrado ser bastante eficiente (Carrer \& Maliga, 1995; Kavanagh et al., 1999). Assim, a seqüência de DNA a ser introduzida no plastoma deve ser flanqueada por regiões homólogas à seqüência de DNA do cloroplasto. Essas seqüências homólogas ao DNA plastidial, utilizadas na construção do vetor de transformação são ditas seqüências alvo e dirigem a introdução do DNA transformante no plastoma. Dessa forma, qualquer gene heterólogo de interesse pode ser introduzido e expresso no genoma cloroplastidial.

A transformação inicia-se pela integração de um segmento de DNA em uma ou algumas cópias do plastoma (o genoma plastidial apresenta-se em múltiplas cópias, em número de 10.000 ou mais por célula em vegetais superiores, Bendich, 1987), de tal forma que o transformante primário é normalmente heteroplásmico, isto é, contém cópias de genomas transformados e não transformados. Após vários ciclos de multiplicação do transformante primário em meio sintético sob forte pressão de seleção (meio de cultura contendo altas concentrações de antibiótico), eventualmente obtém-se plantas homoplásmicas (quando todas as cópias do plastoma estão alteradas uniformemente), Maliga (1993), Bock \& Hagemann (2000), Maliga (2004). Dessa forma, transformantes plastidiais estáveis podem ser obtidos, apresentando diversas vantagens quando comparados a transformantes nucleares, incluindo altos niveis de expressão e acúmulo protéico, a possibilidade de expressão de múltiplos transgenes como 'operons', a ausência de efeitos de posição e silenciamento gênico e a segurança ambiental 
garantida pela característica herança maternal do transgene (revisado em Bock \& Hagemann, 2000; Hager \& Bock, 2000 e Maliga, 2004).

Até 2001, somente o genoma plastidial de fumo (Nicotiana tabacum) vinha sendo transformado de forma rotineira em plantas superiores. A transformação de cloroplastos de plantas de tomate nesse ano (Ruf et al., 2001), rompeu a barreira de extensão da tecnologia para espécies de interesse agronômico, ainda estagnada somente em um único evento em batata (Sidorov et al, 1999) e gerou expectativas bastante otimistas. Transformação estável de cloroplastos de tomate resultou, em adição à alta expressão do transgene introduzido em tecidos foliares, em também elevados níveis de expressão em frutos, com potencial de até $20 \%$ da proteína solúvel total celular. Este valor representa metade da expressão relatada em tecidos foliares das plantas transformadas, embora, mesmo assim, representando nível de expressão de cerca de até 50 vezes maior que aqueles relatados em transformações nucleares tidas como casos de alta expressão. Como conseqüência, esse sistema, de potencial alto nivel de expressão em cromoplastos de frutos de tomate, disponibiliza uma nova tecnologia para a introdução e expressão de caracteres agronômicos ou biotecnológicos em plantas de tomate por meio da transformação de cloroplastos (genomas plastidiais). Isto abre novas possibilidades para manejo de resistências, modificações metabólicas e uso de plantas cultivadas como verdadeiras fábricas de compostos biofarmacêuticos (Bock, 2001; Bock \& Khan, 2004). Plantas apresentam grande potencial para a produção de vacinas, anticorpos e substâncias terapêuticas (revisado em Giddings et al., 2000 e em Job, 2002), especialmente quando considerada a tecnologia de transformação de cloroplastos como ferramenta de opção para a introdução e expressão dos transgenes (Daniell et al., 2002; Bock e Khan, 2004). Quaisquer dessas substâncias se produzidas em cromoplastos ou outros plastídeos de frutos de tomate representariam uma fonte prontamente disponivel mediante consumo do fruto. 
Dentre as linhas de pesquisa mais atuais da tecnologia de transformação de cloroplastos, merecem destaque a expressão de genes para a produção massal de proteinas e/ou seus produtos e a alteração de vias metabólicas para o acúmulo de compostos de interesse farmacêutico, nutricional ou biotecnológico. Somatotropina humana (Staub et al.,2000), vacina contra cólera (Daniell et al., 2001), tétano (Tregoning et al., 2003) e parvovirose canina (Molina et al., 2004) foram produzidas com sucesso pela transformação de genomas plastidiais de fumo. Somatotropina, acumulada em niveis superiores a $7 \%$ da proteína total solúvel celular em fumo transplastômico, mostrou-se pela primeira vez sofrer dobramento correto durante $o$ processamento e montagem da proteina em sistemas recombinantes. As vacinas contra tétano, parvovirose canina e cólera, produzidas por expressão de antígenos específicos em cloroplastos de fumo, mostraram-se efetivas em promover imunização em ratos após administração oral. Nos três casos, os niveis de expressão obtidos, variando entre 10 a $30 \%$ da proteina total solúvel celular, mostraram-se adequados para suprir as doses de antígenos necessárias para indução de resposta imune por administração oral ou nasal por meio de massa vegetal reduzida. Vacinação oral resulta em resposta imune sistêmica em adição à resposta em mucosas, sendo mais efetiva que a vacinação parenteral e de especial interesse uma vez que diversos agentes infecciosos colonizam ou invadem tecidos epiteliais (Molina et al., 2004). Buscando-se elucidar a potencialidade da tecnologia na modificação genética de vias metabólicas, plantas de fumo, também modificadas em seu genoma plastidial, mostraram ser capazes de acumular altos teores de trealose em tecidos foliares por modificação do metabolismo de carbono (Lee et al., 2003) e serem passiveis de modificações de sucesso no metabolismo de aminoácidos (Zhang et al., 2001) ou ácidos graxos (Madoka et al., 2002). A trealose, normalmente não acumulada em plantas de fumo, é um dissacarídeo não redutor de grande utilidade industrial e médica, capaz de estabilizar 
enzimas, proteínas e auxiliar a conservação de órgãos para transplante durante seu transporte. 


\section{MATERIAL E MÉTODOS}

Isolamento dos genes s/r0089 e slr0090: DNA total de Synechocystis sp. PCC6803 foi isolado segundo protocolo descrito em Williams (1988). As regiões codificadoras dos genes s/r0089 e s/r0090 foram amplificadas via PCR (Reação da Polimerase em Cadeia) pelo uso dos primers específicos slr00895':CATGGTTTACCATGTTAGGCCTAA, s/r0089-3': TTTTTCTAGACTAAAGG CTTTATCCCCGTTA, s/r0090-5':CATGGAATTCGACTATCTTCATTTATAC e slr0090-3':TTTTTCTAGATTATGGCACTTCTAACTGTTTTTC desenhados com base nas seqüências dos genes disponiveis no banco de dados: Cyanobase The Genome Database for Synechocystis sp. strain PCC6803 (http://uww. kazusa.or.jp/cyano/). Os fragmentos amplificados foram separados em gel de agarose $1 \%$ e purificados com a utilização do kit "CONCERT ${ }^{\mathrm{TM}}$ Nucleic Acid Purification System (GibcoBRL)" seguindo as especificações do fabricante.

Construção dos vetores de transformação de cloroplastos: Três vetores de transformação (plJB30, plJB31 e plJB32) foram construídos pela substituição da região codificadora do gene nptll (sítios Ncol/Xbal) no vetor de transformação pRB96 (cedido por Ralph Bock, derivado de Ruf et al., 2001, não publicado) conforme segue: (i) pela região codificadora do gene s/r0089, (ii) pela região codificadora do gene s/r0090, e (iii) pelas regiões codificadoras de s/r0089 e s/r0090 intercaladas apenas pela região intergênica original em Synechocystis. A região codificadora do gene nptll foi eliminada do vetor pRB96 por clivagem no sítio de restrição para a enzima Ncol, seguida de 
tratamento da extremidade coesiva resultante com Mung Bean nuclease para geração de extremidades abruptas e, por fim, clivagem com Xbal. As regiões codificadoras de interesse foram ligadas ao vetor resultante dos tratamentos anteriores após clivagem da região 3' dos produtos de PCR pela enzima Xbal. Seqüenciamento das regiões codificadoras inseridas foi realizado para confirmação das seqüências e da correta inserção do quadro de leitura no cassete de expressão.

Sequenciamento das regiōes codificadoras dos genes s/r0089 e s/r0090 clonadas: Seqüenciamentos foram realizados em sequenciador automatizado ABI 3100 (Applied Biosystems) usando BigDye Terminators (Applied Biosystems) e os protocolos estabelecidos no Laboratório de Biotecnologia Agrícola e Genômica do Departamento de Ciências Biológicas, ESALQ/USP. O software Vector NTI Suite 5.0 foi utilizado para montagem dos contigs. Os alinhamentos para determinação de identidade entre os contigs (seqüências obtidas) e as seqüências gênicas originais (regiões codificadoras) foram realizados através do pacote ClustalW, disponivel via internet (http://clustalw genome.ad.jp/).

Material vegetal para transformação genética de cloroplastos: Folhas jovens obtidas a partir de plantas de tomate (cultivares IAC-Santa Clara e IPA6) germinadas in vitro em meio MS (Murashige \& Skoog, 1962) foram utilizadas para bombardeamento de microprojéteis e obtenção de transformantes. Plantas de fumo (Nicotiana tabacum, cv. Petit Havana) foram da mesma forma cultivadas e utilizadas em experimentos de transformação genética.

Preparo dos plasmídeos para bombardeamento: Os plasmídeos plJB30, plJB31 e plJB32 foram inseridos em Escherichia coli linhagem DH5 $\alpha$ por transformação de células competentes (Sambrok et al., 2001). Maxipreps foram preparados com QIAGEN® Plasmid Maxi Kit Tip 500 (Cat. No. 12162), 
conforme especificações do fabricante. Os preparos foram quantificados em espectrofotômetro e confirmados por meio de análise de restrição seguida de eletroforese em gel de agarose $1 \%$ e coloração com brometo de etídio.

Transformação de cloroplastos de tomate e fumo e regeneração de plantas transplastômicas homoplásmicas: Experimentos de transformação de cloroplastos foram realizados segundo procedimento descrito por Ruf et al. (2001) no Instituto de Bioquímica e Biotecnologia de Plantas da Universidade de Münster, Münster, Alemanha, sob supervisão do Prof. Dr. Ralph Bock. Folhas jovens de tomate e fumo foram bombardeadas (biobalística) com partículas de ouro $(0,6 \mu \mathrm{m})$ carregando o DNA vetor através de bombardeador DuPont PDS1000He, discos de ruptura de 1100psi e distância do alvo de 10 $\mathrm{cm}$. Para preparos de partículas suficientes para 10 bombardeamentos foram utilizados $2 \mathrm{mg}$ de ouro, $25 \mu \mathrm{g}$ de plasmídeo vetor, $250 \mu \mathrm{l}$ de $\mathrm{CaCl}_{2} 2,5 \mathrm{M}$ e 50 $\mu$ de espermidina $0,1 \mathrm{M}$. As folhas bombardeadas foram seccionadas em segmentos de cerca de 9 e $25 \mathrm{~mm}^{2}$ para tomate e fumo, respectivamente, e transferidas para meio RMOP (Svab et al., 1990; Svab \& Maliga, 1993) contendo 0 antibiótico espectinomicina $(500 \mathrm{mg} / \mathrm{L})$ para seleção de transformantes primários. Segmentos de calos ou brotos resistentes à espectinomicina (prováveis transformantes) foram transferidos para meio RMOP fresco contendo espectinomicina e estreptomicina (500 mg/L cada) para dupla seleção.

Extração de DNA e análises de PCR: DNA total de calos ou brotos resistentes foi isolado pelo método baseado em CTAB desenvolvido por Doyle \& Doyle (1990). Reações de PCR foram realizadas conforme protocolo padrão (45s a $94^{\circ} \mathrm{C}, 1,5 \mathrm{~min}$ a $55^{\circ} \mathrm{C}, 1,5 \mathrm{~min}$ a $72^{\circ} \mathrm{C} ; 30$ ciclos) usando pares de primers específicos para os genes s/r0089 e s/r0090 (s/r0089-5', s/r0089-3', s/r0090-5' e 
s/r0090-3') e o gene quimérico marcador aadA (P5': 5'-AACCTCCTATAGA CTAGGC-3' e P3': 5'-AGCGAAA TGTAGTGCTTAACG-3', Ruf et al., 2001).

Indução de homoplasmia e análise das plantas: Plantas regeneradas em meio RMOP contendo espectinomicina e estreptomicina $(500 \mu \mathrm{g} / \mathrm{ml}$ cada) são consideradas regenerantes primários e consecutivas subculturas em meio contendo espectinomicina $(500 \mu \mathrm{g} / \mathrm{ml})$ induzem a homoplasmia (todas as cópias do genoma foram modificadas). Brotos oriundos da terceira geração de subcultivo foram isolados para enraizamento e condução das plantas à maturidade para confirmação da homoplasmia por análise da progênie. Devido ao maior periodo de seleção inicial e gerações sucessivas de regeneração, transformantes primários de tomate foram confirmados via Southern blot após três gerações consecutivas de regeneração in vitro.

Enraizamento e transferência de regenerantes para solo: Brotos regenerados de fumo e tomate foram isolados dos tecidos calosos de origem e transferidos para meio RM (sais de Murashige e Skoog, 1962) livre de fitorreguladores para enraizamento. Calos de tomate que não regeneraram diretamente em meio RMOP foram transferidos para meio RM adicionado de 0,2 mg/L IAA e $3 \mathrm{mg} / \mathrm{L}$ BAP para regeneração de brotos (Ruf $t$ al., 2001) e posterior enraizamento. Brotos enraizados foram transferidos para substrato comercial e aclimatados em câmaras de crescimento sob condições controladas $\left(25^{\circ} \mathrm{C} / 16 \mathrm{~h}, 20^{\circ} \mathrm{C} / 8 \mathrm{~h}\right)$.

Produção de sementes e análise de progênie: Brotos aclimatados em condições controladas foram conduzidos à maturidade e produção de sementes em câmara de crescimento. Eventuais problemas de machoesterilidade inicial foram solucionados por fertilização cruzada manual utilizando pólen de plantas não transformadas. As sementes produzidas foram colhidas e secas. Em fumo, cerca de 200 sementes por planta foram semeadas em meio 
contendo espectinomicina $(250 \mu \mathrm{g} / \mathrm{ml})$ para análise de progênie e identificação de plantas homoplásmicas. A análise não foi realizada para tomate e a homoplasmia foi verificada por meio de análise de RFLP e Southern blot.

Análise Fenotípica: Plantas transplastômicas homoplásmicas de fumo, em adição ao controle não transformado, foram germinadas em substrato comercial e conduzidas à produção de sementes em 3 diferentes condições de intensidade luminosa (baixa: $60 \mu$ moles de fótons $/ \mathrm{m}^{2}$; normal: $200 \mu \mathrm{moles} / \mathrm{m}^{2}$; e alta: $400 \mu \mathrm{moles} / \mathrm{m}^{2}$ ) e sob condições de temperatura e fotoperíodo controlados $\left(25^{\circ} \mathrm{C} / 16 \mathrm{~h}, 20^{\circ} \mathrm{C} / 8 \mathrm{~h}\right)$. Todas as plantas foram analisadas visualmente em comparação ao controle não transformado.

Extração de DNA e Southern Blot: DNA total de plantas de tomate enraizadas e aclimatadas em câmara de crescimento, assim como de plantas de fumo germinadas e conduzidas à maturidade em mesma câmara, foi isolado de folhas pelo método baseado em CTAB desenvolvido por Doyle \& Doyle (1990). Análises de RFLP e Southern Blot foram conduzidas conforme procedimento descrito em Ruf et al. (2001) para identificação de plantas homoplásmicas e confirmação da inserção dos genes de interesse. DNA total, clivado pelas enzimas de restrição Pstl e BamHI, foi separado por eletroforese em gel de agarose $0,8 \%$, transferido para membranas Hybond XL (Amersham Pharmacia) e utilizado para análise de Southern blot por hibridização com as sondas radioativas $\left(\alpha-{ }^{32} \mathrm{P}\right)$ descritas abaixo. Clivagem dos plastomas transformados $\mathrm{e}$ não transformados de tomate e fumo com as enzimas de restrição Pstl e BamHl geram fragmentos de 7,3 ou $8,3 \mathrm{~kb}$ (construções simples e dupla) e 4,0 $k b$, respectivamente.

Preparo de fragmentos para sondas específicas para os genes s/r0089, s/r0090 e para análise de homoplasmia: as regiões codificadoras dos genes 
s/r0089 e s/r0090 contidas nos plasmídios plJB30 e plJB31 foram digeridos com as enzimas de restrição Ncol/Xbal e Hincll/Xbal, gerando fragmentos de $886 \mathrm{pb}$ e $990 \mathrm{pb}$, respectivamente. Os fragmentos gerados foram separados por eletroforese em gel de agarose, purificados pelo kit GFX (Amersham Pharmacia) e utilizados para marcação com $\alpha-{ }^{32} \mathrm{P}$ em tampão RapidHyb seguindo as instruções do fabricante (Amersham/Pharmacia) e hibridização nos experimentos de Southern Blot e Northern Blot (Ruf $t$ al., 2001). O fragmento Styl/Pstl derivado do vetor pRB96 (Figura 4) foi utilizado para marcação (conforme anteriormente) e Southern blot nas análises de homoplasmia.

\section{Análise dos níveis de transcrição (Extração de RNA e Northern Blot): RNA} total de plantas transplastômicas de tomate e fumo foi isolado de folhas através do reagente TriFast ${ }^{\circledR}$ conforme protocolo descrito e sugerido pelo fabricante (Amersham Pharmacia). RNA total foi separado por eletroforese em gel contendo formamida, transferido para membranas Hybond XL (Amersham Pharmacia) e utilizado para análise de Northern blot por hibridização com as sondas radioativas $\left(\alpha-{ }^{32} \mathrm{P}\right)$ específicas para os genes s/r0089 e s/r0090 acima descritas, conforme procedimentos adotados em Ruf et al. (2001)

Extração e separação de tocoferóis em fumo (HPLC): Padrões comerciais de $\alpha$-, $\delta$ - e $\gamma$-tocoferol foram utilizados em testes preliminares de análise por HPLC (cromatografia líquida de alta precisão) conforme metodologias propostas por diversos autores, incluindo, Abid \& Mounts (1997), Torre et al. (2001), otimizado em Gómez-Coronado e Barbas (2003) e Gómez-Coronado et al. (2004), com pequenas modificações, Luhua et al. (2004), Schledz et al. (2001) e Fraser et al. (2000). Extração de tocoferóis de folhas de fumo foi conduzida conforme protocolo proposto em Torre et al. (2001), otimizado em Gómez-Coronado e Barbas (2003) e Gómez-Coronado et al. (2004), com pequenas modificações, conforme segue: 5 gramas de folhas foram coletados 
e secos em microondas por 2,5 minutos a 600 Wattts, macerados em cadinho de porcelana e armazenados em dessecador a vácuo e escuro até serem utilizados. Extração dos tocoferóis foi realizada por adição de $400 \mu \mathrm{l}$ de metanol a $25 \mathrm{mg}$ de macerado em tubos de microcentrifuga. Após homogeneização em vortex (rotação máxima), as amostras foram submetidas a sonicação por 1 minuto $(25 \mathrm{KHz})$ e centrifugação a $2000 \mathrm{~g} / 3 \mathrm{~min}$. O sobrenadante foi transferido para novo tubo e submetido a mais uma etapa de centrifugação (2000g/10min) em detrimento de filtração. $10 \mu \mathrm{l}$ do extrato foram injetados no sistema de HPLC para deteç̧ão e quantificação de $\alpha$ - e $\gamma$-tocoferol. A separação cromatográfica foi realizada em sistema de fase móvel composto por água, metanol e acetonitrila. Água purificada para HPLC (sistema Milli-Q, Millipore) foi utilizada como fase móvel $A$ e acetonitrila:metanol $(70: 30, v / v)$ contendo $0,1 \%$ de ácido acético $(v / v)$ como fase móvel $B$. De $t=0$ a $t=24$ minutos a composição do eluente variou em gradiente linear de 85 a 100\% de B. Uma etapa isocrática em $100 \%$ de B por 12 minutos é realizada para eluição de compostos menos polares. Novo gradiente de 100 a $85 \%$ de B em 5 minutos foi realizado para retomada das condições iniciais de separação. A separação se deu em fluxo de $2 \mathrm{ml} / \mathrm{min}$ e a deteç̧ão por fluorescência, $\lambda_{E m}=295 \mathrm{~nm}$ e $\lambda_{E x}=340 \mathrm{~nm}$. Identificação dos picos foi realizada por comparação do tempo de retenção de padrões puros de $\alpha-, \beta-, \gamma-$ e $\delta$-tocoferol. Este teste não foi conduzido para tomate.

Teste preliminar de resistência ao herbicida isoxaflutole em préemergência em fumo: Sementes de fumo (Nicotiana tabacum var. Petit Havana; não transformado e plantas transplastômicas plJB30\#23B, plJB31\#03A e plJB32\#14B) foram desinfestadas e germinadas inicialmente em meio MS (Murashige and Skoog, 1962) contendo 0,1 ppm de isoxaflutole, ingrediente ativo (Provence ${ }^{\circledR}, 75 \%$ i.a., Bayer CropScience). Em seqüência ao resultado, sementes de fumo não transformado e a linha transplastômica 
plJB31\#03A foram desinfestadas e germinadas em meio MS contendo $0,1,2$, $4,8,16,32$ e $64 \mathrm{ppm}$ de isoxaflutole (i.a.). Análise visual das plantas, 15 dias após germinação, permitiu observar o efeito do herbicida nas plantas controle e transplastômicas. Plantas susceptíveis ao herbicida são caracterizadas por perda de pigmentação e desenvolvimento comprometido. 


\section{RESULTADOS E DISCUSSÃO}

\subsection{Isolamento dos genes s/r0089 e s/r0090 de Synechocystis sp. PCC6803}

As regiões codificadoras dos genes s/r0089, s/r0090 e s/r0089 + slr0090 (como um operon) foram amplificadas por PCR (Polymerase Chain Reaction) via DNA total de Synechocystis sp. PCC6803 usando o kit comercial "ELONGASE Amplification System (GibcoBRL)" de acordo com as especificações do fabricante. Os produtos de PCR obtidos foram separados em gel de agarose $1 \%$ conforme mostrado na Figura 3 e purificados para a construção dos vetores de transformação plJB30, plJB31 e plJB32. A Figura 3 mostra ainda, que os fragmentos obtidos apresentaram os tamanhos esperados para as regiões codificadoras dos genes s/r0089, s/r0090 e s/r0089 + slr0090: 954 pb, 1020pb e 1997pb, respectivamente. A ausência de bandas inespecíficas nos produtos de PCR mostra a amplificação correta das regiões de interesse, conforme seria esperado em função do caráter estritamente especifico dos pares de primers utilizados nas reações de PCR.

Vale ressaltar que os primers desenhados para as regiões 5' amplificadas foram adicionados de um nucleotídeo citosina $(C)$ antes do códon de iniciação da tradução ATG. Por sua vez, primers desenhados para as regiões 3' amplificadas tiveram seus códons de terminação adaptados para compor um sítio de restrição para a enzima Xbal. Tais estratégias foram utilizadas para facilitar a clonagem e manutenção de sítios de restrição na 
construção final.

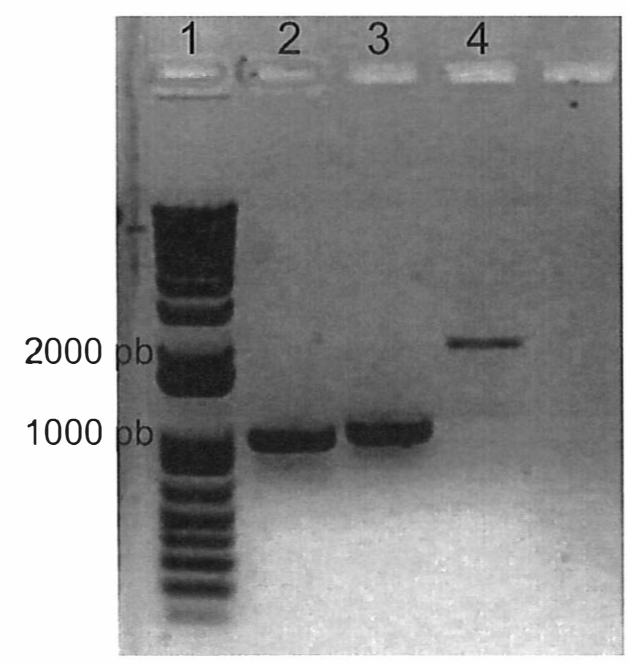

Figura 3 - Regiões codificadoras dos genes slr de Synechocystis PCC6803 amplificadas via PCR e separadas em gel de agarose $1 \%$ corado com brometo de etídio. 1. 1Kb DNA Plus Ladder; 2. s/r0089; 3. s/r0090; 4. s/r0089 + s/r0090

\subsection{Construção dos vetores de transformação plJB30, plJB31 e plJB32}

As regiões codificadoras amplificadas (s/r0089, s/r0090 and s/r0089 + slr0090) foram digeridas com a enzima de restrição Xbal (região 3') e clonadas nos sítios Xbal e Ncol/MungBean nuclease no vetor pRB96, substituindo a região codificadora do gene nptll originalmente clonada nos sítios Xbal e Ncol, gerando os três vetores construídos: 1. plJB30 contendo a região codificadora do gene s/r0089; 2 . plJB31 contendo a região codificadora do gene s/r0090; e 3. plJB32 contendo as regiões codificadoras dos genes s/r0089 e s/r0090 a serem expressas como um operon. Como resultado, todas as construções apresentam os genes s/r sob controle da expressão pelo promotor Patpl e o terminalizador Trps14 de cloroplastos de fumo, conforme exposto no esquema apresentado na Figura 4. Originalmente, em fumo, o 
promotor Patpl apresenta dois sítios de iniciação da transcrição, -131 e -208, o primeiro promovido por uma seqüência promotora consenso "-35" tipicamente procariótica (-35 consensus-type promoter - CT) responsável pela promoção da expressão em cloroplastos (plastídeos verdes), e o segundo promovido por uma seqüência promotora não-consenso (non-consensus type II promoter NCII) responsável pela expressão em plastídeos não-verdes (Miyagi et al., 1998; Berger, 2000). Tais características levam a inferir que transformação de cloroplastos com os genes s/r em estudo sob controle do promotor Patpl levarão à expressão das enzimas correspondentes tanto em plastídeos verdes como em não-verdes, como por exemplo nos cromoplastos de frutos de tomate. $O$ indicativo da atividade promotora do Patp/ pôde ser verificada pela expressão de resistência ao antibiótico espectinomicina em Escherichia coli transformada com plasmídeo contendo o cassete de expressão Patpl-aadA-Trps14 em estudos prévios do Laboratório de Biologia Molecular e Genômica, Departamento de Ciências Biológicas, ESALQ/USP (Berger, 2000). Uma vèz se tratando de um promotor tipicamente procariótico (tipo $\sigma^{70}$ ), expressão controlada pelo promotor Patpl seria realmente esperada em E. coli desde que a região codificadora em questão tenha sido corretamente clonada, ou seja, fazendo parte do quadro de leitura.

Análise de restrição dos clones obtidos e selecionados para as três construções é mostrada na Figura 5. Os plasmídeos recombinantes obtidos para as três construções foram clivados com as enzimas de restrição $X b a l$ e $\mathrm{Ncol}$ e os produtos das digestões separados em gel de agarose $1 \%$ corado com brometo de etídio. Os padrões de banda encontrados corroboram os resultados esperados com base na análise dos mapas de restrição das seqüências gênicas originais (mapas não mostrados). 


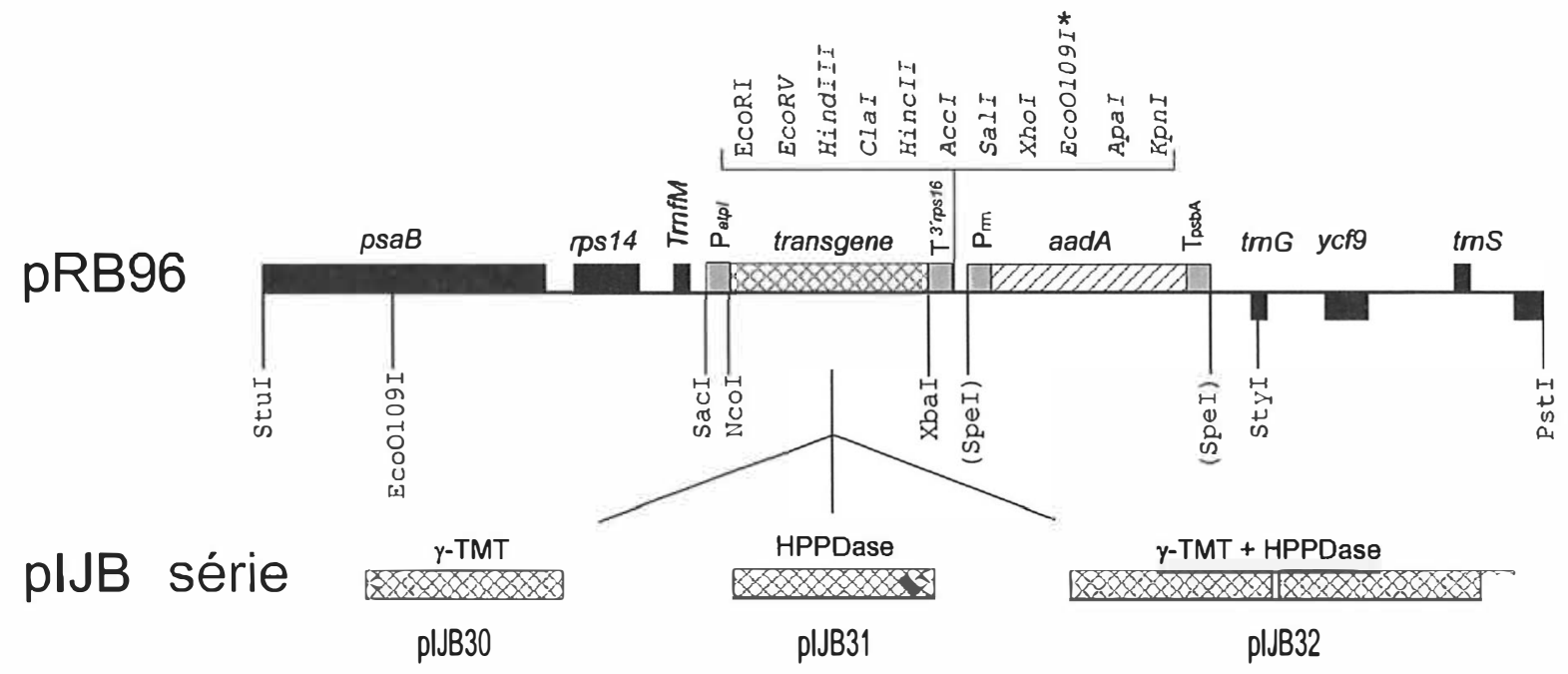

Figura 4 - Vetores de transformação de cloroplastos via recombinação homóloga plJB30, plJB31 e plJB32. Substituição da região codificadora do gene nptll pelos genes slr. Em todas as construções os genes slr encontram-se sob controle da expressão pelo promotor Tatpl e terminalizador Prps14

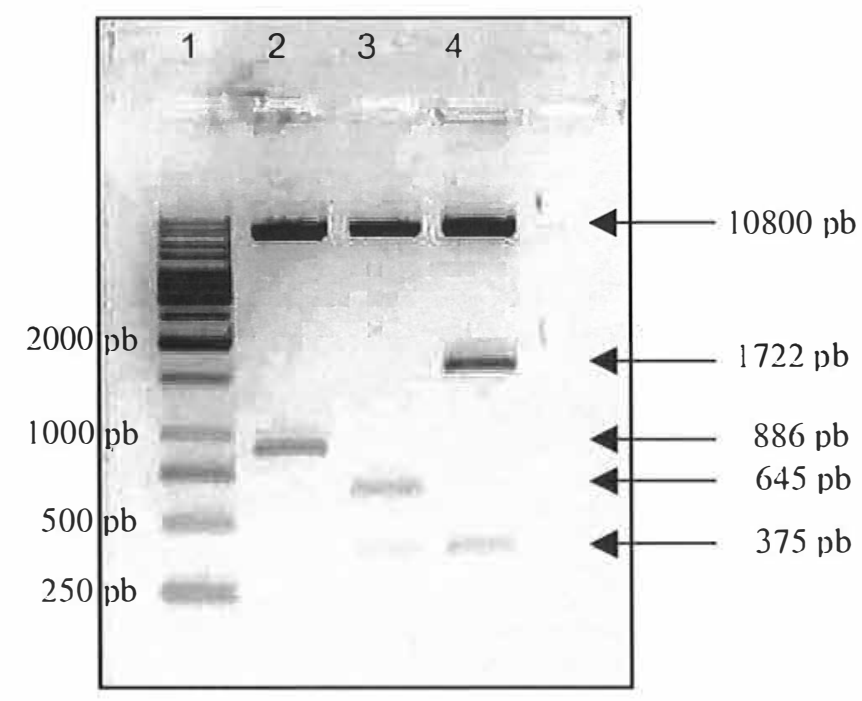

Figura 5 - Análise de restrição dos clones obtidos e selecionados para as construções plJB30, plJB31 e plJB32. Os plasmídeos foram digeridos com as enzimas de restrição $X$ bal e $\mathrm{Ncol}$ e separados em gel de agarose 1\%. 1. 1kb DNA Ladder; 2. plJB30; 3. plJB31; 4. plJB32 


\subsection{Seqüenciamento e confirmação das regiões codificadoras clonadas}

Seqüenciamento dos vetores foi realizado para confirmar a autenticidade das regiões codificadoras s/r0089, s/r0090 and s/r0089 + s/r0090 amplificadas e clonadas conforme exposto anteriormente. Alinhamentos das seqüências obtidas com as seqüências gênicas originais (CyanoBase) mostraram identidade total em todos os casos, excluindo modificações previstas, indicando a possibilidade do uso das construções na tentativa de expressão das enzimas $\gamma$-TMT e HPPDase em plastídeos de tomate e fumo (alinhamentos não apresentados por serem idênticos às seqüências existentes no banco de dados). Tais modificações previstas foram alterações dos dois últimos códons da região codificadora do gene s/r0089 GTT e TGA para GTC e TAG, compondo a seqüência GTCTAG de reconhecimento da enzima de restrição $X b a l$ necessária à clonagem da região no vetor de transformação. Os resultados obtidos mostram a fidelidade de cópia da enzima polimerase utilizada nas amplificações (kit ELONGASE Amplification System, GibcoBRL).

\subsection{Bombardeamento de explantes foliares de tomate e fumo para transformação de cloroplastos}

Para realização dos experimentos de bombardeamento os plasmídeos vetores isolados de Escherichia coli foram digeridos com as enzimas de restrição Xbal/Ncol para confirmação dos padrões de restrição já apresentados na Figura 4.

Os experimentos foram realizados no Instituto de Bioquímica e Biotecnologia de Plantas da Universidade de Münster, Münster, Alemanha. Foram realizados 150 bombardeamentos conforme apresentado na Tabela 1, incluindo os três vetores construídos, fumo e duas variedades de tomate (IPA-6 e IAC-Santa Clara), utilizando partículas de ouro de 0,6 $\mu \mathrm{m}$, discos de ruptura 
de 1.100 psi e distância de $10 \mathrm{~cm}$. Após os ensaios de biobalística os explantes foliares foram seccionados em segmentos de aproximadamente 9 e $25 \mathrm{~mm}^{2}$ para tomate e fumo, respectivamente, e inoculados em meio RMOP contendo o antibiótico espectinomicina $(500 \mu \mathrm{g} / \mathrm{ml})$ para seleção inicial de células transformadas.

Possiveis transformantes primários foram obtidos para fumo a partir de 4 a 6 semanas após os bombardeamentos e para tomate após 2 a 3 meses, corroborando os resultados já relatados em literatura (discutido em Ruf et al., 2001). Brotos de fumo obtidos das três construções foram confirmados serem transformados por transferência para meio RMOP contendo espectinomicina e estreptomicina (500 $\mu \mathrm{g} / \mathrm{ml}$ cada, constituindo assim dupla seleção) e posteriormente por PCR através de amplificação do gene marcador seletivo aadA. A Figura 6 mostra transformantes primários de fumo para as construções plJB30 e plJB31 após 4 semanas decorridas do primeiro experimento de bombardeamento.

Para tomate, foram confirmados 1 transformante primário (calos ou brotos) para a construção plJB31 e 6 transformantes primários para a construção plJB32 por transferência para meio RMOP contendo espectinomicina e estreptomicina $(500 \mu \mathrm{g} / \mathrm{ml}$ cada) e testes de PCR. No entanto, por motivos não esclarecidos, somente um calo transplastômico da variedade IPA-6 transformado com a construção pIJB32 foi capaz de regenerar plantas. Observou-se que a variedade IPA-6 é capaz de regenerar brotos diretamente em RMOP, enquanto que a variedade Santa Clara apresenta crescimento na forma de calos (estrutura decorrente de crescimento desordenado e indiferenciado de células) que precisam ser transferidos para meio específico de indução de regeneração contendo $0,2 \mathrm{mg} / \mathrm{L}$ de $I A A$ e $3 \mathrm{mg} / \mathrm{L}$ de BAP (Ruf et al., 2001). Embora regeneração de calos de tomate IAC-Santa Clara tenha sido alcançada por Ruf et al. (2001), não se obteve sucesso no presente trabalho. A Figura 7 mostra os primeiros transformantes primários obtidos da construção plJB32. Plantas transplastômicas derivada de IPA-6 para 
a construção plJB32 encontram-se em fase de propagação, no laboratório de Bioquímica e Biotecnologia de Plantas da Universidade de Münster, para produção de sementes e posterior análise de teor em tocoferóis.

Tabela 1 - Número total de bombardeamentos realizados nos experimentos de sucesso para transformação de cloroplastos de tomate e fumo com os vetores plJB30, plJB31 e plJB32. Vetores (construções) e espécies/variedades utilizadas são mostrados na tabela

\begin{tabular}{ccccc}
\hline $\begin{array}{c}\text { Planta } \\
\text { Vetor }\end{array}$ & $\begin{array}{c}\text { Tomate } \\
\text { IPA-6 }\end{array}$ & $\begin{array}{c}\text { Tomate } \\
\text { Santa Clara }\end{array}$ & $\begin{array}{c}\text { Fumo } \\
\text { Petit havana }\end{array}$ & Totais \\
\hline plJB30 & 10 & 10 & 20 & 40 \\
plJB31 & 20 & 5 & 25 & 50 \\
plJB32 & 20 & 10 & 30 & 60 \\
Totais & 50 & 25 & 75 & 150 \\
\hline
\end{tabular}

\subsection{Confirmação da transformação por teste de dupla seleção}

Segmentos de cerca de $2-3 \mathrm{~mm}^{2}$ dos brotos de possiveis transformantes primários de fumo e tomate, foram transferidos para meio RMOP contendo os antibióticos espectinomicina e estreptomicina $(500 \mu \mathrm{g} / \mathrm{ml}$ cada). O meio de cultura contendo ambos os antibióticos impõe dupla pressão de seleção, possibilitando a distinção entre brotos transformados e eventuais mutantes espontâneos para resistência à espectinomicina. Expressão do gene quimérico aadA, presente nas construções plJB30, plJB31 e plJB32, confere resistência a ambos antibióticos Mutantes espontâneos para resistência à espectinomicina não são capazes de desenvolver-se sob a ação da 
estreptomicina e, portanto, somente células contendo plastídeos realmente transformados regeneram sob a dupla pressão de seleção. A Figura 8 ilustra o teste descrito acima realizado com possíveis brotos transplastômicos de fumo. Somente as células que mantiveram crescimento, em forma de calo ou de novos brotos regenerados já podem ser consideradas geneticamente transformadas.

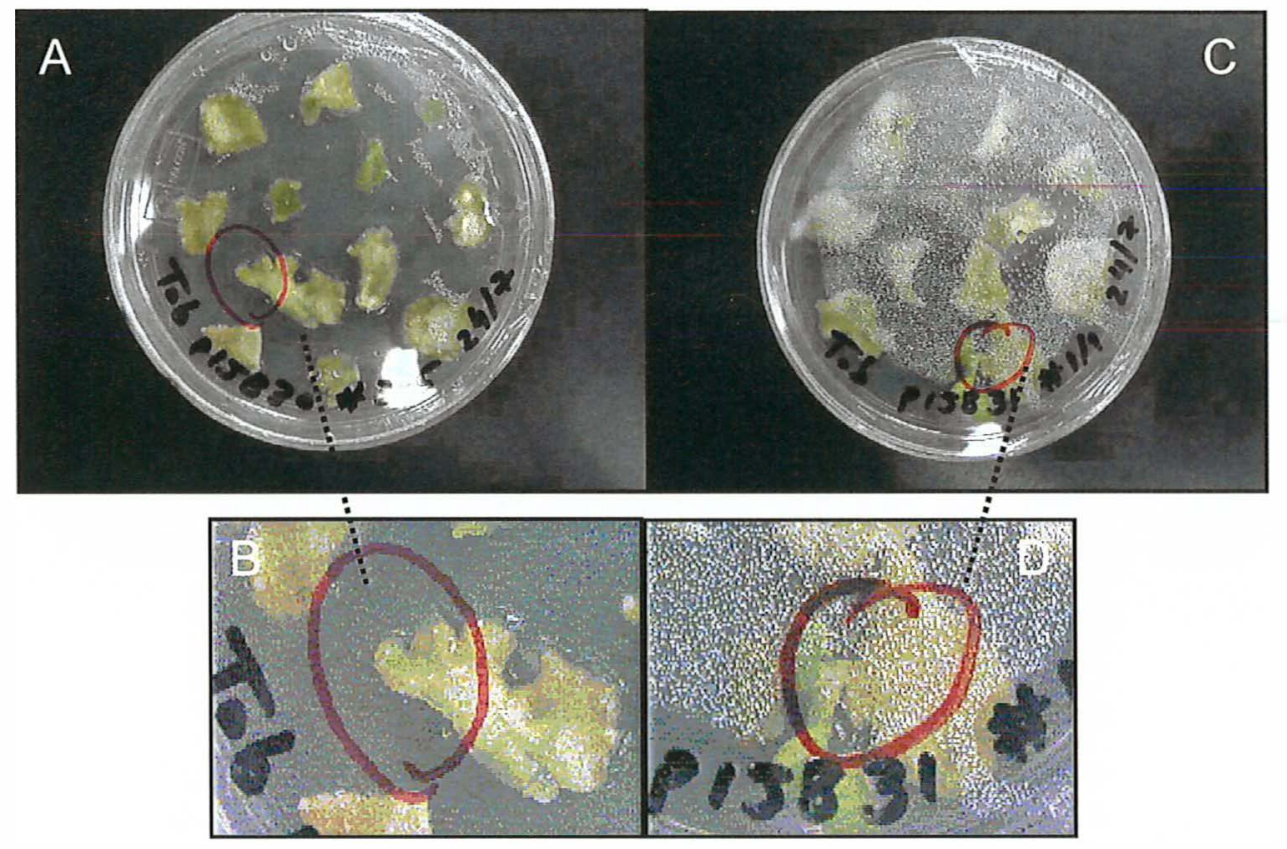

Figura 6 - Transformantes primários de fumo obtidos 4 semanas após o primeiro experimento de bombardeamento para as construções plJB30 (A e B) e plJB31 (C e D) 


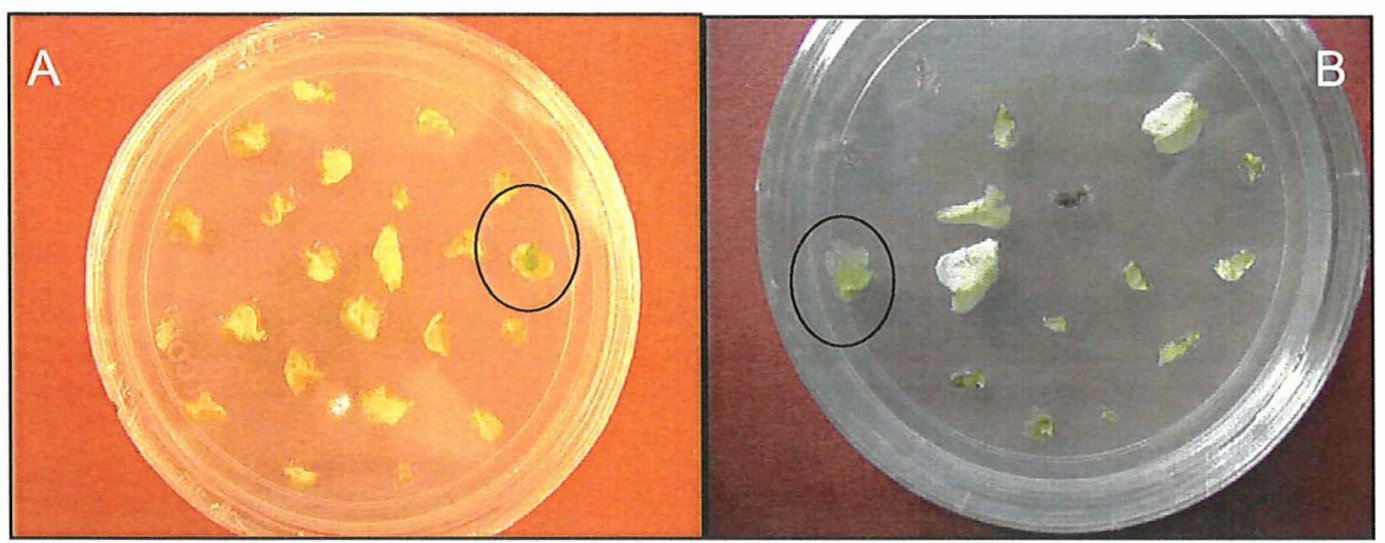

Figura 7 - Transformantes primários de tomate para a construção plJB32. A. variedade IPA-6; B. variedade Santa Clara

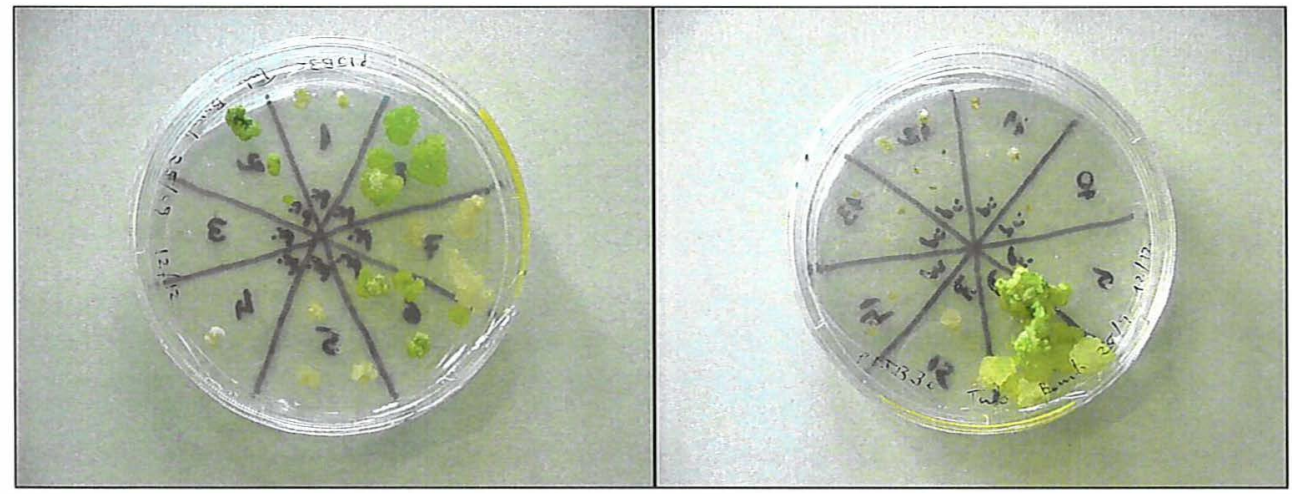

Figura 8 - Plantas transplastômicas de fumo transformado com a construção plJB30 regenerando em meio RMOP contendo os antibióticos espectinomicina e estreptomicina $(500 \mu \mathrm{g} / \mathrm{ml}$ cada). 


\subsection{Análises iniciais de homoplasmia: análise de progênie em fumo e Southern blot em tomate}

Brotos oriundos de transformantes transplastômicos de fumo foram isolados e transferidos para meio de enraizamento (RM) após a terceira geração consecutiva de regeneração em meio seletivo (RMOP contendo $500 \mu \mathrm{g} / \mathrm{ml}$ de espectinomicina). Brotos enraizados e transferidos para solo foram aclimatados e conduzidos à maturidade em câmaras de crescimento sob condições controladas $\left(25^{\circ} \mathrm{C} / 16\right.$ horas de luz; $20^{\circ} \mathrm{C} / 8$ horas de escuro). As sementes foram coletadas, secas em temperatura ambiente e utilizadas para análise de progênie. Sementes desinfestadas (cerca de 200 por planta transformada) foram semeadas em meio RM contendo $250 \mu \mathrm{g} / \mathrm{ml}$ de espectinomicina e incubadas sob condições controladas para germinação. Plantas homoplásmicas devem dar origem exclusivamente a plântulas normais e verdes (resistentes ao antibiótico) e plantas heteroplásmicas devem segregar em plântulas resistentes e susceptíveis, estas, no caso, brancas, por inibição da tradução cloroplastidial, como resultado da ação da espectinomicina (Maliga, 1993). A Figura 9 mostra os resultados de duas plantas transplastômicas analisadas, uma homoplásmica e outra heteroplásmica.

Duas plantas transplastômicas homoplásmicas de fumo para cada construção (plJB30, plJB31 e plJB32) foram selecionadas para semeadura em substrato comercial provendo material para as análises fenotípicas, moleculares e bioquímicas. A seleção foi baseada na consistência dos dados da análise de progênie, ou seja, foram selecionadas as plantas homoplásmicas selecionadas pelo teste de germinação em presença do antibiótico com maior número de sementes germinadas no teste. 


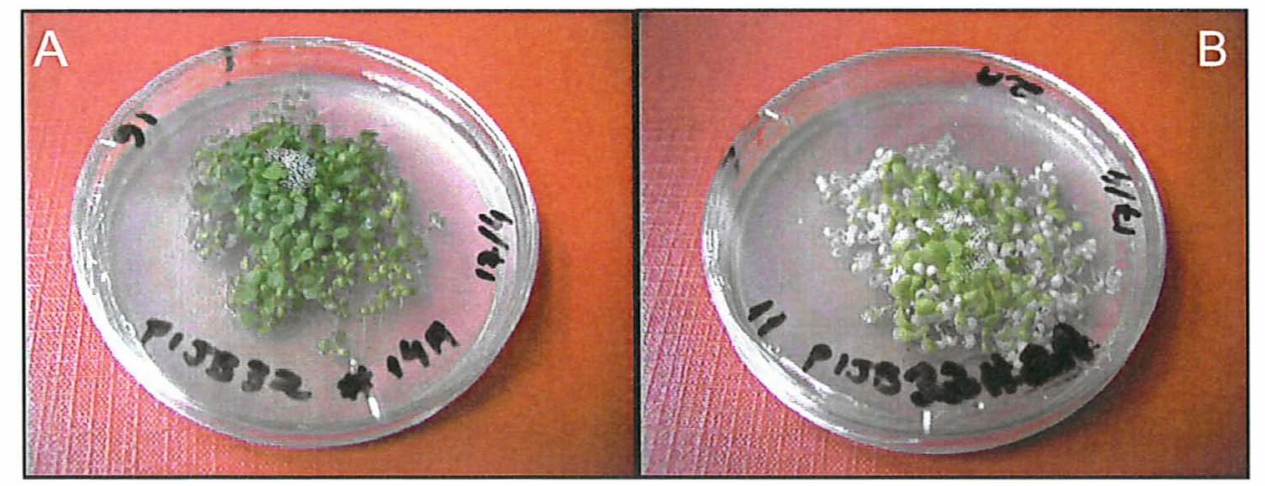

Figura 9-Análise de progênie de plantas transplastômicas de fumo. A: sementes de planta homoplásmica germinadas em meio RM contendo espectinomicina $(250 \mu \mathrm{g} / \mathrm{mL})$, todas as plântulas apresentam-se resistentes ao antibiótico, mostrando fenótipo normal de coloração verde; B. sementes de planta heteroplásmica germinadas em meio RM contendo espectinomicina $(250 \mu \mathrm{g} / \mathrm{mL})$, caracterizadas por segregação traduzida na presença de plântulas resistentes normais e plântulas albinas

Plântulas de tomate var. IPA-6, transformadas com a construção plJB32 (únicas que regeneraram), foram enraizadas em RM livre de fitorreguladores e em seguida foram transferidas para vasos e aclimatadas em câmara de crescimento sob condições controladas (Figura 10). Folhas destas plantas foram usadas para identificação de plantas homoplásmicas via Southern blot. DNA total foi isolado, clivado com as enzimas de restrição $P s t l / B a m H I$ e separado em gel de agarose $0,8 \%$. Hibridação com sonda radioativa $\left(\alpha{ }^{32} P\right)$, fragmento Styl/Pstl de pRB96, seguida de exposição e revelação, resultou na imagem apresentada na Figura 11. Plantas heteroplásmicas, ou seja, contendo genomas originais e genomas transformados apresentam as duas bandas, de $8,3 \mathrm{~kb}$ e 4,0 kb respectivamente. Plantas homoplásmicas para a transformação apresentam somente a banda equivalente a 8,3 kb. Dessa forma, 4 plantas transplastômicas analisadas demonstraram ser homoplásmicas para a inserção dos genes aadA, s/r0089 e s/10090: plJB32/1A, plJB32/1B, plJB32/1G e plJB32/1J. Essas plantas 
constatadas homoplásmicas foram mantidas em desenvolvimento sob condições controladas para produção de frutos e sementes. Propagação vegetativa das plantas, por enraizamento de brotos laterais, também foi realizada para garantir a manutenção das plantas.

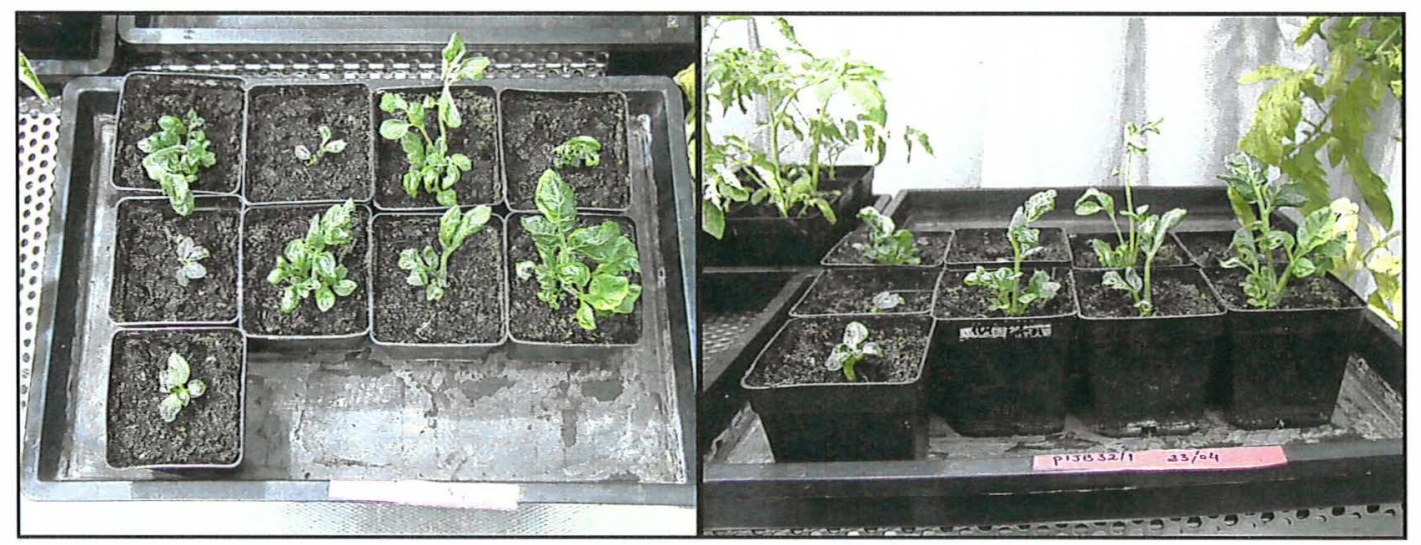

Figura 10 - Plantas transplastômicas de tomate IPA-6 transferidas para substrato comercial para aclimatação e desenvolvimento em câmara de crescimento sob condições controladas

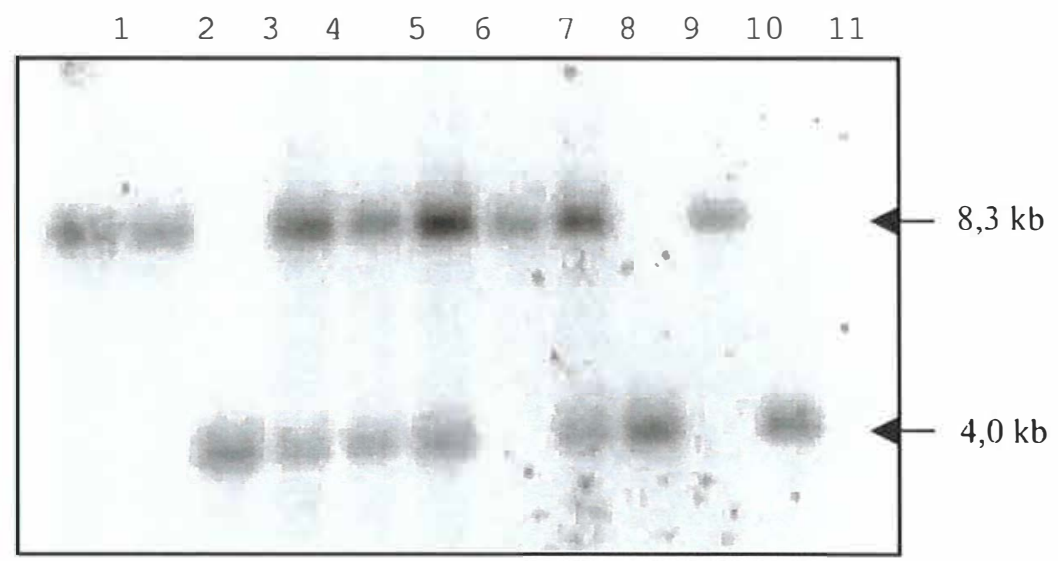

Figura 11 - Análise de RFLP e Southern blot de plantas transplastômicas de tomate IPA-6 para a construção plJB32. 1 a 10: plantas transplastômicas plJB32/1 A, B, C, D, E, F, G, H, I e J respectivamente; 11: planta não-transformada da variedade IPA-6. Plantas $A, B, G$ e J foram constatadas homoplásmicas para a trasnformação 


\subsection{Análise fenotípica em fumo}

Plantas transplastômicas homoplásmicas de fumo, em adição ao controle não transformado, foram germinadas em substrato comercial e conduzidas à maturidade e produção de sementes em três diferentes intensidades luminosas (baixa: $60 \mu$ moles $/ \mathrm{m}^{2}$; normal: $200 \mu \mathrm{moles} / \mathrm{m}^{2}$; e alta: $400 \mu \mathrm{moles} / \mathrm{m}^{2}$ ) sob condições de temperatura e fotoperíodo controlados $\left(25^{\circ} \mathrm{C} / 16 \mathrm{~h}, 20^{\circ} \mathrm{C} / 8 \mathrm{~h}\right)$.

Dois representantes transplastômicos homoplásmicos foram selecionados para cada construção. Uma planta por representante foi conduzida à maturidade e produção de sementes, em adição a uma planta não transformada (controle), para cada condição de intensidade luminosa estudada.

Observação visual do crescimento e desenvolvimento das plantas sugeriu não terem ocorrido quaisquer modificações aparentes no fenótipo em decorrência das alterações genéticas realizadas. Esse resultado pode ser visualizado nas figuras 12, 13 e 14, que mostram as plantas após início do florescimento. Foi observado um pequeno retardo no desenvolvimento e florescimento da planta transplastômica plJB30\#16A, no entanto não existem evidências suficientes para inferir que tal diferença foi decorrente da alteração genética cloroplastidial. Pode ter ocorrido por variação genotípica e fenotípica normal da população.

Uma vez que a via dos tocoferóis deriva da via dos isoprenóides, alteração do fluxo normal da via para produção massiva de tocoferóis poderia acarretar em deficiência de isoprenóides, tais como carotenóides, prenilquinonas, quinonas ou outros, com conseqüentes anormalidades metabólicas e seus reflexos no fenótipo. Os dados da análise fenotípica aqui apresentados sugerem que tais modificações não ocorreram, ou não foram significantes, fato importante desde que o objetivo do projeto é a alteração exclusiva da via dos tocoferóis. Análise detalhada do espectro de carotenóides 
e clorofilas via HPLC, em adição à análise de tocoferóis, pode ser considerada para reforçar tal conclusão e/ou caracterizar possiveis alterações metabólicas.

Por outro lado, poderia ser esperado algum efeito positivo de um possivel aumento massivo na produção de tocoferóis nas plantas submetidas à alta intensidade luminosa. Evidências experimentais sugerem que tocoferóis têm papel na proteção de membranas contra estresse oxidativo e controle do estado redox celular (Munné-Bosch \& Falk, 2003). Foram observadas precocidade sutil no florescimento e pequena redução no crescimento vertical das plantas sob condições de alta intensidade luminosidade em comparação à condição normal, no entanto sem qualquer significativa diferença visual entre as plantas transformadas e o controle dentro da mesma luminosidade. Tal resultado pode sugerir que a intensidade luminosa adotada não foi suficiente para gerar estresse oxidativo para que o papel do provável aumento de tocoferóis na proteção de membranas fosse detectado. Uma vez comprovado o aumento de tocoferóis nas plantas transformadas (análise ainda a ser realizada), novas análises fenotípicas adotando-se intensidades luminosas mais elevadas para indução de estresse oxidativo poderão ser realizadas. Desde que condições que levem plantas controle ao estresse oxidativo sejam alcançadas, o papel dos tocoferóis na proteção de membranas poderá ser especulado. 


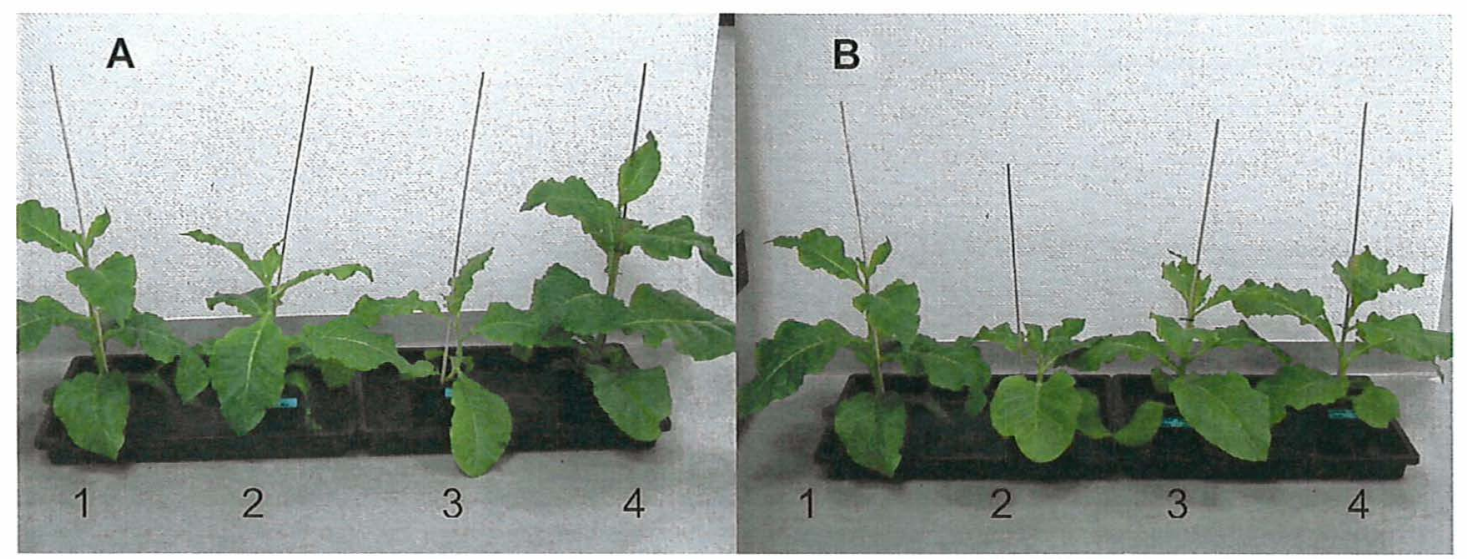

Figura 12 - Plantas de fumo cultivadas em câmara de crescimento sob condições de baixa intensidade luminosa $\left(60 \mu\right.$ moles $\left./ \mathrm{m}^{2}\right)$. 1: controle, planta não transformada; 2: plantas homoplásmicas para a contrução plJB30; 3: plantas homoplásmicas para a construção plJB31; 4: plantas homoplásmicas para a construção plJB32

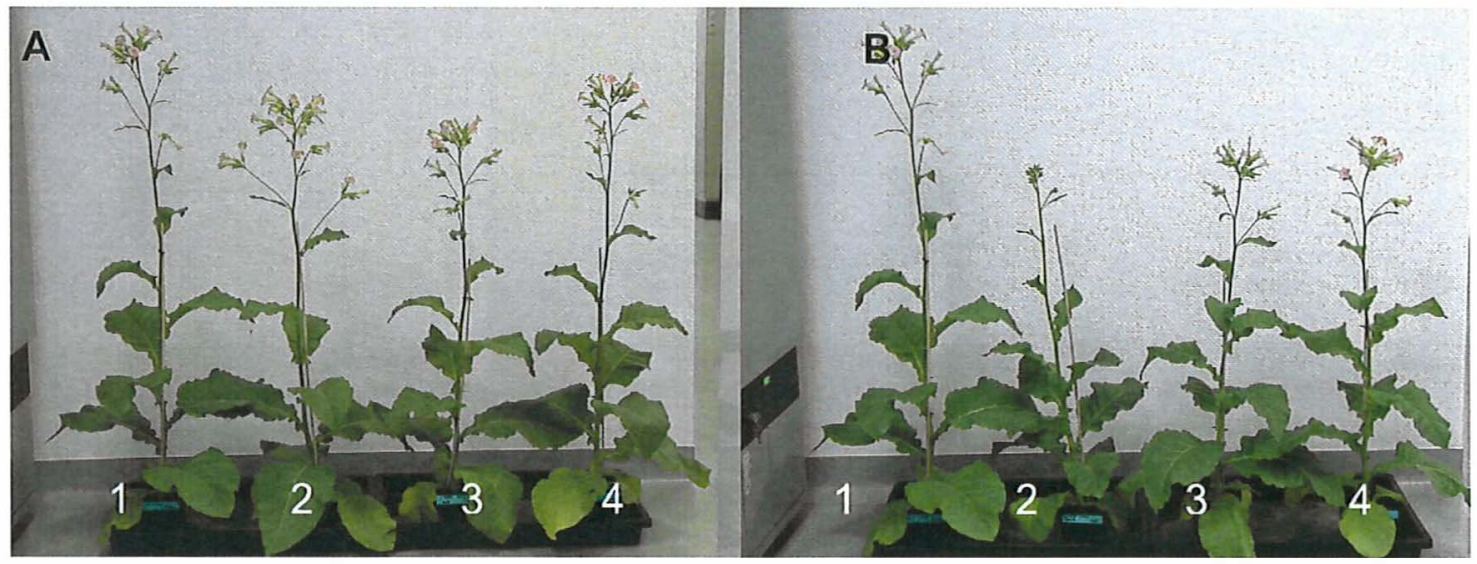

Figura 13 - Plantas de fumo cultivadas em câmara de crescimento sob condições de intensidade luminosa normal $\left(200 \mu\right.$ moles $\left./ \mathrm{m}^{2}\right)$. 1: controle, planta não transformada; 2: plantas homoplásmicas para a contrução plJB30; 3: plantas homoplásmicas para a construção plJB31; 4: plantas homoplásmicas para a construção plJB32 


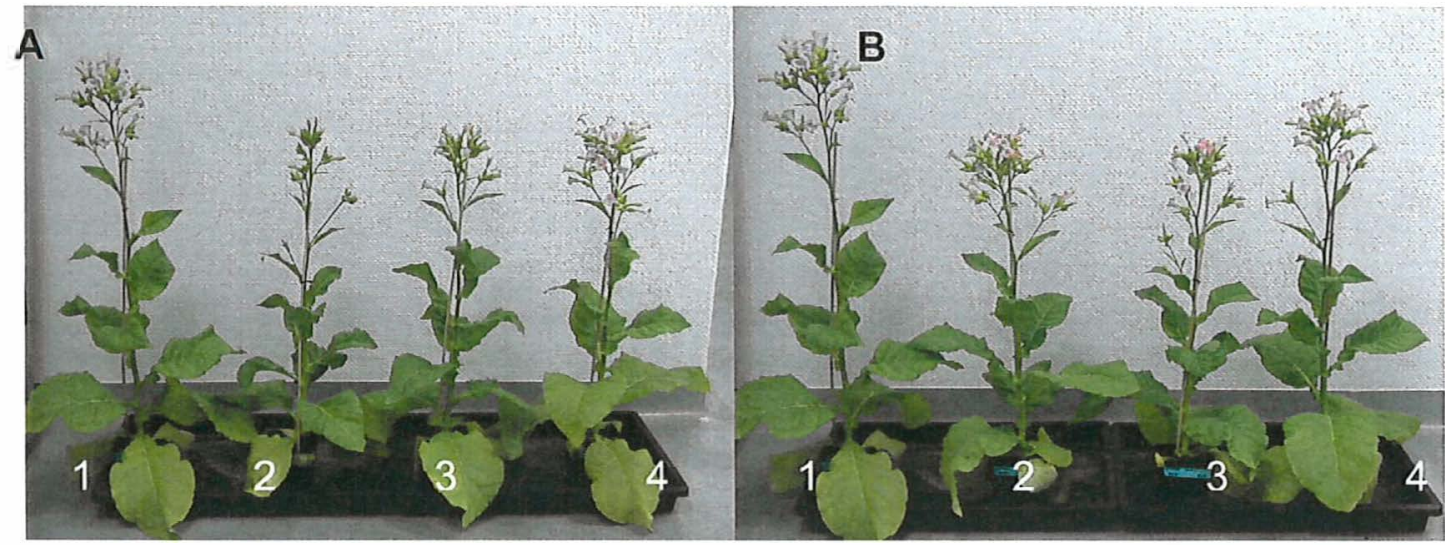

Figura 14 - Plantas de fumo cultivadas em câmara de crescimento sob condições de alta intensidade luminosa $\left(400 \mu\right.$ moles $\left./ \mathrm{m}^{2}\right)$. 1: controle, planta não transformada; 2: plantas homoplásmicas para a contrução plJB30; 3: plantas homoplásmicas para a construção plJB31; 4: plantas homoplásmicas para a construção plJB32.

\title{
4.8 Confirmação da integração dos genes de interesse e re-confirmação da homoplasmia em progênies das plantas transplastômicas
}

\begin{abstract}
Visando a confirmação da homoplasmia de plantas provenientes de sementes de plantas transplastômicas de fumo previamente estudadas, análises de RFLP e Southern blot foram realizadas com material vegetal derivado da geração T2. Com mesmo objetivo, plantas de tomate T0 propagadas vegetativamente por enraizamento de brotos laterais foram analisadas. DNA total foi isolado, clivado com as enzimas de restrição Pstl e $B a m \mathrm{HI}$, separado por eletroforese em gel de agarose $0,8 \%$ e hibridizado com sonda radioativa específica para detecção da região de integração dos vetores de transformação (fragmento Styl/Pstl de pRB96). Os resultados são apresentados na Figura 15. Todas as plantas transplastômicas mostraram-se homoplásmicas, contendo apenas a banda referente ao fragmento do plastoma original acrescido da seqüência do gene marcador aadA e do(s) gene(s) da via dos tocoferóis inseridos. Conforme esperado, plantas não transformadas apresentam banda de 4,0 kb, plantas contendo apenas um dos genes de
\end{abstract}


interesse $7,2 \mathrm{~kb}$ (s/r0089 ou s/r0090) e plantas contendo a inserção dos genes s/r0089 e s/r0090 8,3 kb. Algumas bandas decorrentes de hibridização cruzada podem ser observadas nas plantas de fumo, porém sendo da mesma forma observadas no controle não transformado, as quais podem ser ignoradas e com certeza não representam cópias adicionais dos genes de interesse. Tais bandas são de comum ocorrência em experimentos da mesma natureza com plantas de fumo e muitas vezes não podem ser eliminadas, mesmo que maior estringência nas condições de hibridização seja adotada (comunicação pessoal, Prof. PhD Ralph Bock, 2004).

Experimento similar ao anterior também foi realizado para deteç̧ão e confirmação da integração correta dos genes s/r0089 e s/r0090 nas plantas transplastômicas. DNA total foi isolado, clivado com as enzimas de restrição Pstl e BamHI, separado por eletroforese em gel de agarose $0,8 \%$ e hibridizado com sondas radioativas específicas para os genes s/r0089 e s/r0090. Os resultados são apresentados na Figura 16. Todas as plantas transplastômicas apresentaram as bandas esperadas, correspondentes ao(s) gene(s) inserido(s). Plantas transformadas com o vetor plJB30 apresentaram banda decorrente da hibridização com a sonda específica para o gene s/r0089. Da mesma forma, plantas transformadas com o vetor plJB31 apresentaram banda decorrente da hibridização com a sonda específica para o gene s/r0090, e plantas transformadas com o vetor plJB32 ambas as bandas. O experimento confirma a inserção correta dos genes de interesse nos plastomas de tomate e fumo nas plantas transplastômicas estudadas, conseqüência da integração dos genes por eventos de recombinação homóloga. 


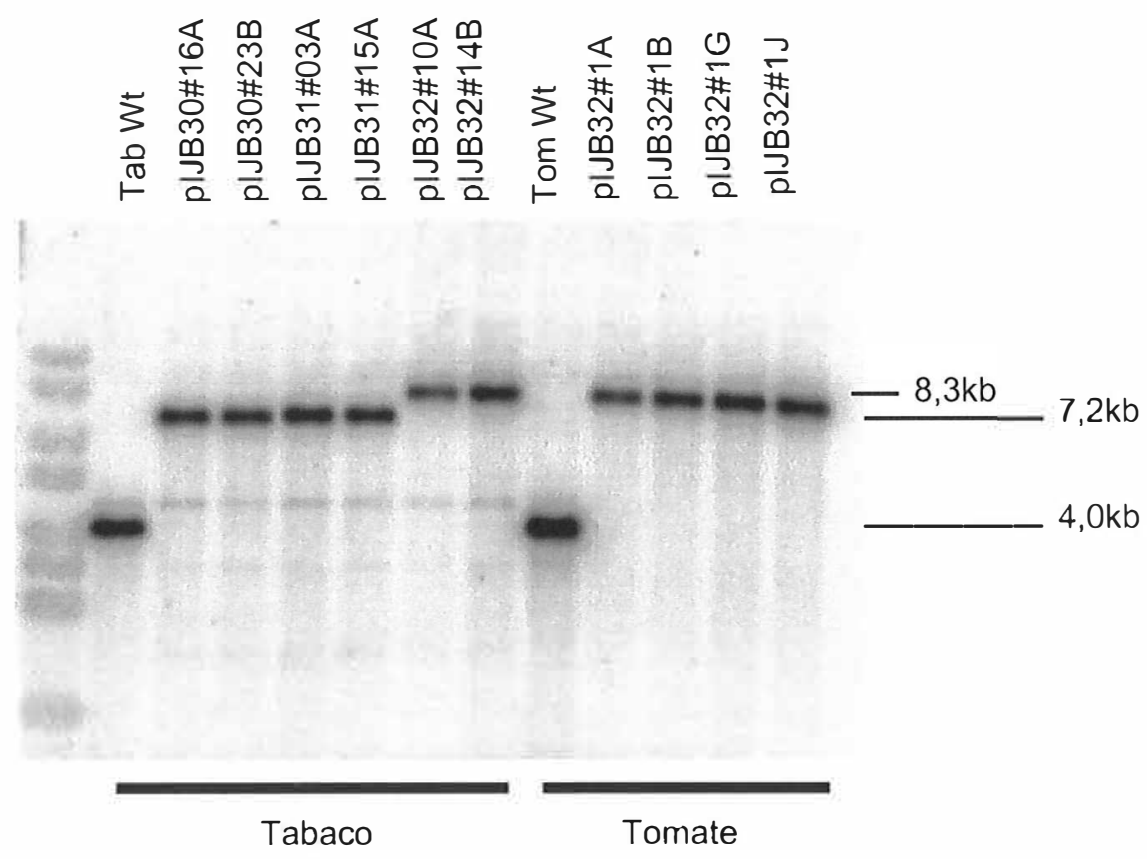

Figura 15 - Análise de homoplasmia das plantas transplastômicas de tomate e fumo estudadas através de RFLP e Southern blot. Fragmentos de plastomas não tranformados TabWt (fumo controle) e TomWt (tomate controle): $4 \mathrm{~kb}$; Fragmentos de plastomas transformados com um dos genes de interesse, slr0089 ou slr0090 e o marcador seletivo aadA: 7,2 kb; Fragmentos de plastomas transformados com os dois genes de interesse s/r0089 e s/r0090 e o marcador seletivo aadA: $8,3 \mathrm{~kb}$ 
Sonda para slr0089

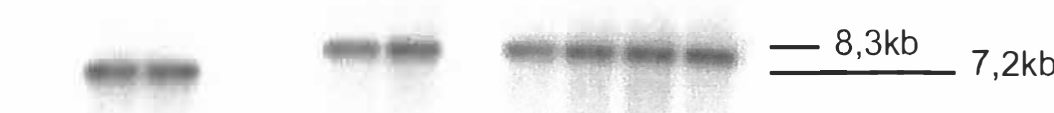

Sonda para slr0090

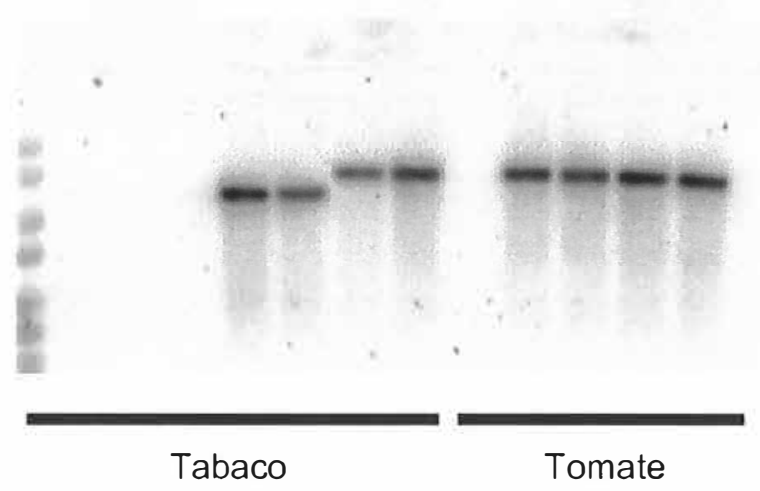

Figura 16 - Análise da integração dos genes s/r0089 e s/r0090 nas plantas transplastômicas de tomate e fumo por RFLP e Southern blot. Controles de fumo (TabWt) e tomate (TomWt): ausência de bandas. Fragmentos de plastomas transformados com um dos genes de interesse, s/r0089 ou s/r0090 e o marcador seletivo aadA: 7,2 kb; Fragmentos de plastomas transformados com os dois genes de interesse s/r0089 e s/r0090 e o marcador seletivo aadA: 8,3 kb

\subsection{Condução dos transformantes de tomate e produção de frutos}

Seleção e regeneração de transformantes cloroplastidiais em tomate são caracteristicamente mais lentas com relação ao que ocorre rotineiramente em fumo (discutido em Ruf et al., 2001). Em adição, o ciclo de vida de uma planta de tomate também é significativamente maior quando comparado ao ciclo de uma planta de fumo, cerca de 4-5 meses contra 2 meses em fumo, aproximadamente. Todos esses fatores, somados aos problemas freqüentes 
encontrados nas câmaras de crescimento com infestações de Phytophtora infestans, levaram a um período mais longo na obtenção das plantas e na condução dos experimentos com tomate. Da mesma forma, essas infestações também devem explicar os primeiros e críticos problemas enfrentados para a produção de frutos e sementes. Somente em março de 2004 foram obtidas as primeiras sementes viáveis de tomate produzidas pela planta transformada plJB32\#1G. Mesmo neste caso os frutos mostraram-se de tamanho bem reduzido quando comparados ao controle não transformado, de planta não infectada por Phytophtora. Plantas controle também infectadas apresentaram da mesma forma frutos de tamanho bastante reduzido, o que sugere que a redução no tamanho de frutos e produção de sementes possa ser efeito da infestação e não de alterações indesejadas causadas pela alteração genética realizada. A Figura 17 mostra os primeiros frutos colhidos nas plantas transformadas e em controle não transformado. É facilmente notada a diferença no tamanho dos frutos. Nessa coleta, somente a planta plJB32\#1G e - controle geraram sementes viáveis (e apenas uma para a planta transformada). A Figura 18 mostra a primeira plântula viável obtida via semente da planta transplastômica plJB32\#1G.

Diante do contexto acima exposto, plantas de tomate ainda encontram-se em crescimento e propagação para produção de frutos e sementes. Todas as análises até o momento realizadas basearam-se em material vegetal coletado de plantas propagadas vegetativamente dos brotos iniciais transferidos para solo. Confirmação dos resultados a partir de plantas T1 geradas de sementes será importante para a comprovação da herança dos caracteres inseridos. 


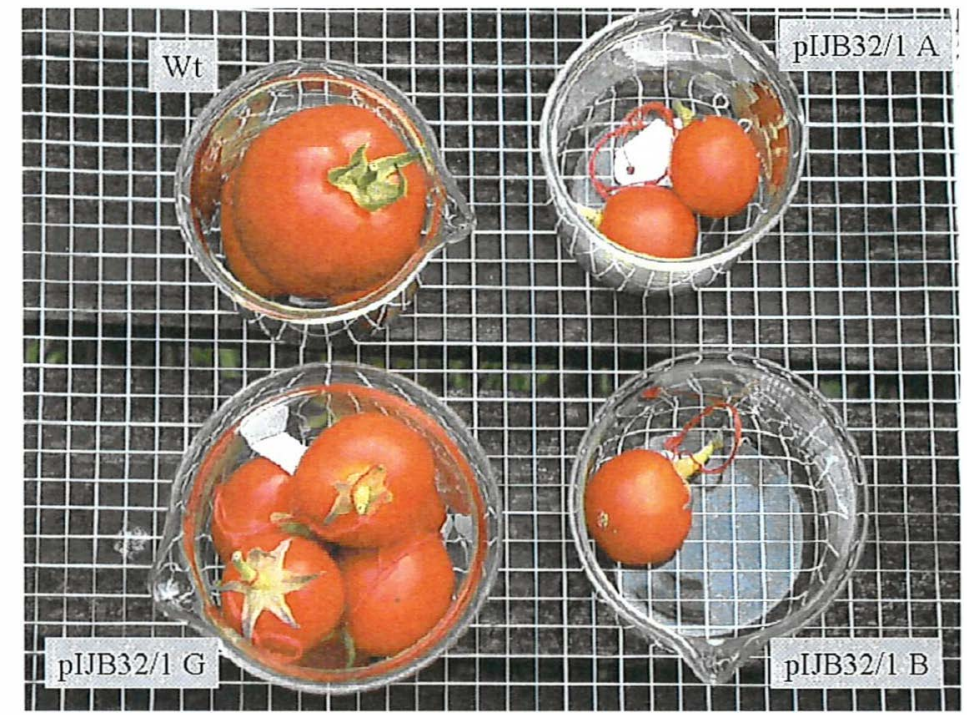

Figura 17 - Frutos da primeira coleta em plantas transplastômicas de tomate para a construção plJB32 contendo os genes s/r0089 e s/r0090 de Synechocystis sp. PCC6903

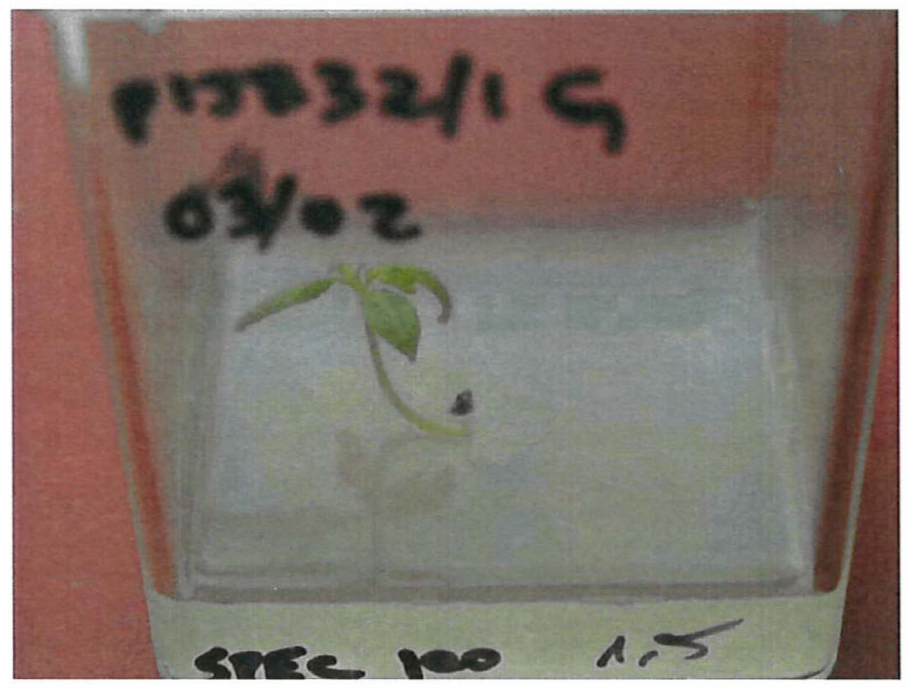

Figura 18 - Primeira plântula obtida através da germinação de semente da planta transplastômica de tomate plJB32/G em meio RM contendo espectinomicina $(100 \mu \mathrm{g} / \mathrm{ml})$ 


\subsection{Seleção de métodos de detecção e separação de tocoferóis por HPLC}

Testes preliminares de separação e detecção de tocoferóis por HPLC (cromatografia líquida de alta precisão) foram conduzidos em primeiro momento utilizando-se coluna de fase reversa $\mathrm{C}_{30}$ (YMC Europe, $5 \mu \mathrm{m}, 4.6 \mathrm{~mm}$ ) no sistema de HPLC ÄKTA Explorer (Amersham Pharmacia), acoplado a duas bombas P910, 4 inlets (A1, A2, B1 B2), válvula manual de injeção e detector de UV (ultra-violeta), admitindo fluxo máximo de $2 \mathrm{ml} / \mathrm{min}$. Nessas condições, vários testes de separação baseados nos sistemas de solventes adotados por Abid and Mounts (1997), Fraser et al. (2000), Schledz et al. (2001) e Luhua et al. (2004) foram conduzidos, no entanto mostraram-se em geral insatisfatórios na separação ou definição de picos de padrões comerciais de tocoferóis. Os melhores resultados, foram obtidos com o sistema de solventes adotado por Luhua et al. (2004) modificado. O solvente metanol:acetonitrila $(90: 10, \mathrm{v} / \mathrm{v})$ foi adotado para separação isocrática dos padrões comerciais $\alpha-, \beta-, \gamma-$ e $\delta$ tocoferol (Merck) em fluxo de $1 \mathrm{ml} / \mathrm{min}$ e detecção a $\lambda=295 \mathrm{~nm}$. No entanto, os primeiros testes com material vegetal, baseado na extração de isoprenóides totais proposta for Fraser e colaboradores (Fraser et al., 2000), não gerou resultados positivos.

Visando seleção e adequação da detecção e separação dos tocoferóis, novas metodologias foram empregadas. O detector de UV, com sensibilidade considerada inadequada para uma boa deteç̧ão foi substituído por fluorímetro (Shimadzu), cuja sensibilidade de detecção por fluorescência é estimada ser 100 vezes maior que aquela apresentada pela detecção por UV (Rupérez et al., 2001). Em adição, coluna de fase reversa $C_{18}$ (Spherisorb ODS-2, $5 \mu \mathrm{m}, 4.6 \mathrm{~mm}$ ) passou a ser utilizada, mantendo-se as demais características do equipamento. Nessas condições, os métodos de separação 
propostos por Torre et al. (2001) e otimizados em Gómez-Coronado \& Barbas (2003) e Gómez-Coronado et al. (2004), foram testados com os padões comerciais e mostraram-se adequados. Avaliação preliminar do método de extração de folhas proposto pelos autores, com modificações de escala de volume, foi realizada. O método simplificado proposto pelos autores por sua rapidez, eliminando a dependência ao trabalho em atmosfera de nitrogênio, pareceu também adequado. Análise detalhada das plantas transformadas deve oferecer informações suficientes para avaliação da consistência do método.

O método permitiu a detecção e separação eficiente ao menos das formas $\alpha$-, $\delta$ - e $\beta$ - $+\gamma$-tocoferol, indicando que o sistema selecionado deve ser adequado para a separação, detecção e quantificação desses tocoferóis nas plantas transplastômicas obtidas por alteração genética do metabolismo de tocoferóis no presente trabalho. Colunas de fase reversa C18 são conhecidas não serem capazes de separar eficientemente $\beta$ - e $\gamma$-tocoferol, análogos de estruturas e massas moleculares extremamente similares, embora mesmo assim sejam as mais utilizadas para a separação e detecção de tocoferóis em extratos vegetais (Rúperez et al., 2001)

\subsection{Ensaio preliminar de resistência ao herbicida isoxaflutole}

Sementes de plantas transplastômicas de fumo (plJB30\#14B, plJB31\#03A e plJB32\#14B) e sementes não transformadas (controle) foram desinfestadas em soluções de álcool etílico $95 \%$ e hipoclorito de sódio $1 \%$ e germinadas em meio MS (Murashige \& Skoog, 1962) adicionado de isoxaflutole. Buscando inicialmente apenas determinar se as plantas transplastômicas de fumo obtidas apresentavam resistência diferenciada ao herbicida, estas foram germinadas em meio contendo $0,1 \mathrm{ppm}$ de isoxaflutole. Plântulas de fumo não transformado e da construção plJB30 (contendo o gene slr0089) foram sensiveis ao herbicida e mostraram-se com pigmentação e 
desenvolvimento comprometidos. Com a hipótese de que expressão do gene s/r0090 que codifica a enzima HPPD possa conferir resistência ao herbicida isoxaflutole, resultados de resistência para as plântulas trabsformadas com as construções plJB31 e plJB32, ambas contendo o gene slr0090, seriam esperados. Plântulas da construção plJB31 (contendo apenas o gene s/r0090) mostraram-se resistentes à dose utilizada, no entanto plântulas da construção plJB32 (construção dupla, com os genes s/r0089 e s/r0090 expressos em transcrito dicistrônico) mostraram-se sensiveis. A Figura 19 mostra os resultados obtidos. Acredita-se, com base neste teste preliminar, que a expressão do cassete dicistrônico introduzido através da construção plJB32 é reduzida em relação à expressão monocistrônica. Análise da sensibilidade ao herbicida pela inserção dos 2 genes será alvo de estudo em continuidade ao trabalho realizado.

Para análise e caracterização mais detalhada das plantas transplastômicas plJB31\#03A, que mostraram potencial de resistência ao herbicida, novo experimento foi conduzido. Sementes controle não transformadas e sementes de plantas plJB31 foram germinadas em meio contendo $0,0,5,1,2,4,8,16,32$ e 64 ppm de isoxaflutole (i.a.). Para as plantas controle $0,5 \mathrm{ppm}$ de isoxaflutole foi suficiente para geração do fenótipo albino decorrente da ação do herbicida e inibição do desenvolvimento. Plântulas pIJB31\#03A apresentaram resistência a $0,5 \mathrm{ppm}$ de isoxaflutole e embora com fenótipo inicialmente albino em concentrações superiores, algumas plantas mostraram capacidade de recuperação do fenótipo normal em 1 ppm e alguma pigmentação nas concentrações de 2, 4 e 8 ppm de isoxaflutole (Figura 20).

Os resultados mostram, novamente, uma resistência ao herbicida maior nas plantas transformadas quando em comparação ao controle, embora tal nivel de resistência seja inferior ao obtido por Rippert et al. (2004) em seus experimentos com transformação nuclear. Plantas de fumo transformadas com o gene HPPD de Arabidopsis thaliana mostraram-se resistentes a até 4 ppm de 
isoxaflutole nos ensaios de Rippert e colaboradores. Uma vez que altos niveis de expressão, bastante superiores àqueles obtidos pela transformação nuclear, são normalmente vantagens estratégicas associadas à transformação de cloroplastos (Bock \& Hagemman, 2000; Maliga, 2004), os resultados aqui obtidos sugerem que o promotor utilizado para dirigir a expressão da região codificadora do gene s/r0090 de Synechocystis, Patpl, não deva ser adequado para gerar elevados niveis de expressão ao menos em tecidos não fotossintetizantes. Análise de tecidos foliares, como por exemplo testes de resistência ao herbicida em pós-emergência ( 3 a 4 folhas verdadeiras), podem contribuir para elucidar o potencial de expressão pelo promotor Patpl em tecidos fotossinteticamente ativos e conseqüentemente maior resistência ao herbicida.

A capacidade de resistência de plântulas de fumo expressando a enzima HPPD abre portas para um novo e interessante aspecto a ser explorado como resultado do presente trabalho. Ensaios em pós-emergência em vasos, como proposto acima, poderão determinar níveis máximos de resistência das plantas transplastômicas ao herbicida e, assim, avaliar a possibilidade de uso do gene s/r0090 de Synechocystis no desenvolvimento de plantas de interesse agronômico expressando a característica de resistência a herbicidas.

Os herbicidas da classe das triketonas, como 0 isoxaflutole (Provence ${ }^{\circledR}$, Bayer CropScience) e o mesotrione (Callisto ${ }^{\circledR}$, Syngenta) inibem a enzima HPPD e são largamente utilizados nas culturas de cana-de-açúcar e milho, uma vez que a diketonitrila (DKN), ingrediente ativo de tais herbicidas, é considerada molécula com atividade herbicida bastante promissora desde 1982 (Lee et al., 1998). Os recentes avanços na transformação de cloroplastos com sucesso nas espécies de soja (Dufourmantel et al., 2004), algodão (Kumar et al., 2004) e cenoura (Kumar et al., 2004b), além da batata (Sidorov et al., 1999) e tomate (Ruf et al., 2001), sugerem em primeiro momento serem estas espécies escolhidas para introdução da resistência aos herbicidas inibidores da HPPD. Nesse aspecto, vale ressaltar que calos transplastômicos de tomate 
variedade Santa Clara transformados com a construção plJB31 foram obtidos no presente projeto, embora até o momento não tenham regenerado brotos e conseqüentemente plantas transformadas. A dificuldade de regeneração de plantas a partir de calos na variedade IAC-Santa Clara foi constatada comum em calos com células que apresentam a integração dos genes do plasmídeo plJB32. A obtenção de plantas transplastômicas de tomate expressando a característica em questão depende de novos experimentos de transformação com a construção pIJB31 utilizando a variedade IPA-6.

Adicionalmente, se for confirmado o baixo potencial de resistência aos herbicidas inibidores da HPPD pelo uso do vetor plJB31, sugere-se a construção de um novo cassete de expressão para o gene s/r0090, cujo controle da expressão da região codificadora do gene s/r0090 seja substituído por um promotor plastidial forte, por exemplo o promotor Prrn, largamente utilizado para superexpressão de trangenes em genomas plastidiais (Maliga, 2003). Niveis de expressão equivalentes a até $45 \%$ da proteína total solúvel celular já foram demonstrados na transformação de cloroplastos de fumo com uso do promotor Prm para expressar o operon cry2Aa2 de Bacillus thurigiensis (De Cosa et al., 2001; revisado em Maliga, 2003).

Conforme apresentado neste trabalho, a tecnologia de transformação de cloroplastos de espécies cultivadas ainda apresenta muitos desafios. Somente resultados de trabalhos como este podem auxiliar a desvendá-los, assim como também demonstrar o enorme potencial biotecnológico para obtenção de plantas com melhores características agronômicas, variedades com maior qualidade nutricional ou mesmo para a produção de biofármacos. 


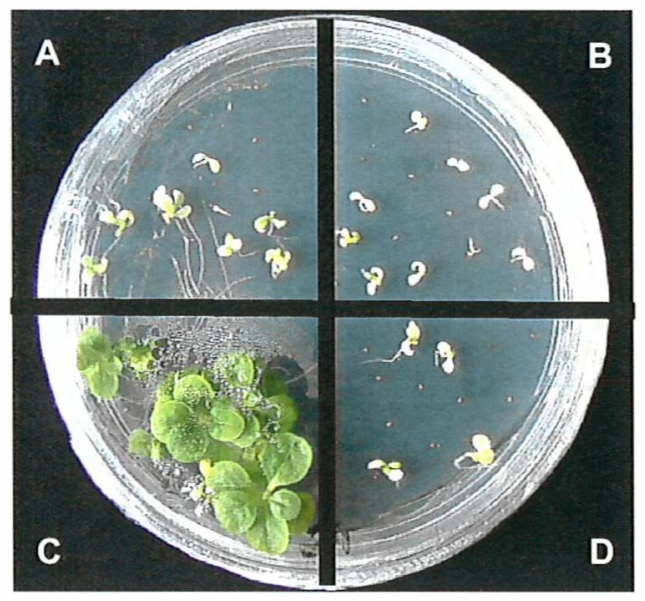

Figura 19 - Teste de resistência ao herbicida isoxaflutole $(0,1 \mathrm{ppm})$ na germinação de sementes. A: fumo não transformado; $B$ : sementes de plantas plJB30\#23B; C: sementes de plantas plJB31\#03A; D: sementes de plantas plJB32\#14B 


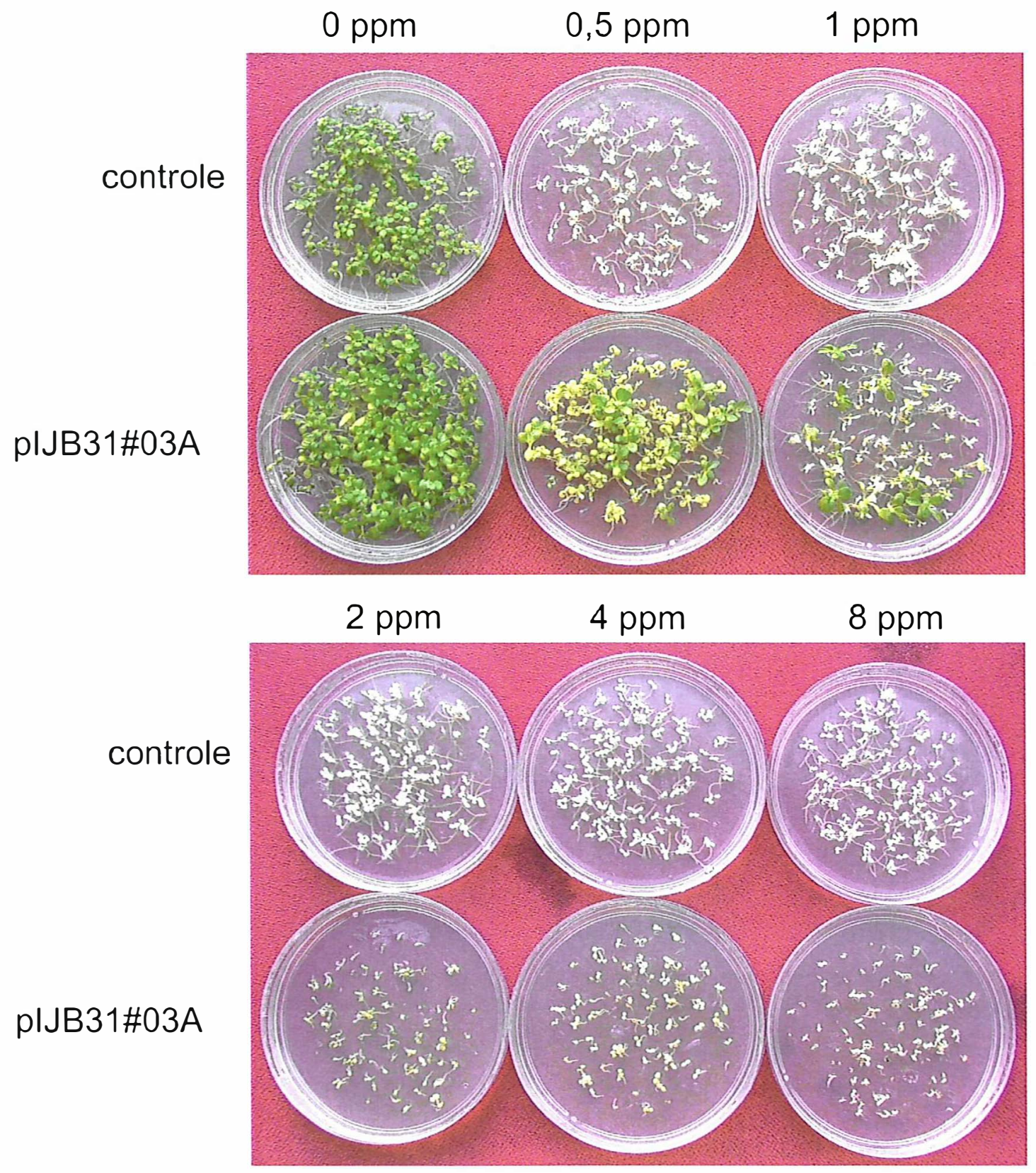

Figura 20 - Teste de germinação de sementes de plantas de fumo controle e plantas pIJB31\#03A em meio RM contendo 0, 0,5, 1, 2, 4 e 8 ppm de isoxaflutole, ingrediente ativo (Provence 750WG, 75\% i.a., Bayer CropScience). Concentrações superiores a $8 \mathrm{ppm}$, equivalentes a 16, 32 e 64 ppm não são mostradas por terem gerado também exclusivamente plântulas albinas e com desenvolvimento comprometido 


\section{DISCUSSÃO FINAL}

Os resultados obtidos no presente trabalho demonstram a viabilidade das estratégias adotadas para a modificação genética de vias metabólicas confinadas em plastídeos. Transformação de cloroplastos em tomate (Ruf et al., 2001) já se mostra como uma alternativa viável à transformação de fumo, única espécie rotineiramente transformada até os dias atuais (revisado em Maliga, 2004).

A introdução das regiões codificadoras dos genes s/r0089 e s/r0090 de Synechocystis sp. PCC6803 em genomas plastidiais de tomate e fumo, representa um primeiro esforço da aplicação da tecnologia de transformação de cloroplastos na engenharia metabólica da via dos tocoferóis. Estudos de sucesso vêm sendo realizados por meio de transformação nuclear de plantas de soja (Van Eenennaam et al., 2003) e alface (Cho et al., 2005) pela introdução e expressão do cDNA de Arabidospis thaliana que codifica a enzima $\gamma$-tocoferol metil transferase $(\gamma$-TMT). O presente trabalho traz informações adicionais em ao menos dois aspectos, a viabilidade de uso da transformação de cloroplastos como estratégia alternativa à transformação nuclear e a proposição do uso de novos genes alternativos aos de Arabidopsis para o aumento do valor nutricional e agronômico (resistência a herbicidas) de plantas cultivadas. Em adição, confirmação do aumento do teor de tocoferóis como resultado da estratégia adotada, gera nova combinação genética de interesse ao melhoramento da característica na espécie estudada, o tomate, assim como o potencial uso de mesma estratégia em espécies distintas. 
Os resultados obtidos com testes preliminares de resistência ao herbicida isoxaflutole refletiram provável nivel baixo de expressão do gene s/r0090 dirigida pelo promotor Patpl. No entanto, tal resultado e conclusão não podem ser extrapolados e devem ser tratados com cautela. Expressão dirigida pelo promotor Patpl é esperada ser diferente em tecidos fotossintetizantes e não-fotossintetizantes devido aos diferenciados sinais de expressão utilizados nessas duas situações distintas nos tecidos e pela atividade bioquímica para reconhecimento do promotor e expressão do gene (caracterizado em Miyagi et al., 1998). Somente após novos testes de resistência ao herbicida em tecidos provenientes de plantas adultas fotossintetizantes (situação de pósemergência) ou pela mensuração direta da expressão gênica dirigida pelo Patpl em tecidos diferenciados, pode-se chegar a uma visão generalizada e conclusiva da questão. No momento, pode ser apenas afirmado que para o objetivo de gerar plantas tolerantes aos herbicidas inibidores da HPPD, a expressão do gene s/r0090 de Synechocystis pelo promotor Patpl não é efetiva. Esforços para a modificação da construção plJB31 com substituição do promotor por outro de caráter forte, tal qual o Prrn (revisado em Maliga, 2003), serão necessários para que tal objetivo seja atingido. Da mesma forma, quando considerada a hipótese de aumento do teor de tocoferóis pelas construções utilizadas, nenhuma conclusão pode ser precipitada antes da completa análise e quantificação dos análogos de tocoferóis nas plantas transplastômicas obtidas. Primeiro porque deverão ser analisados os distintos tecidos vegetais destas plantas. Segundo porque niveis de expressão elevados não parecem ser necessários ao menos para a conversão eficiente de $\gamma$ - em $\alpha$-tocoferol pela $\gamma$-TMT, uma vez que os trabalhos desenvolvidos em soja e alface por transformação nuclear, onde os niveis de expressão são caracteristicamente baixos, mostraram-se positivos.

Análise mais detalhada das plantas transplastômicas obtidas, com caracterização de teores de tocoferóis, niveis de expressão e potenciais de resistência aos herbicidas inibidores da HPPD, com certeza resultarão em 
dados suficientes para uma visão mais clara da potencialidade das estratégias utilizadas e o direcionamento das modificações para garantir o sucesso na alteração positiva do metabolismo de tocoferóis, de grande interesse nutricional e terapêutico, assim como na geração de plantas resistentes a herbicidas, que apresentam grande importância agronômica e no agronegócio. 


\section{CONCLUSÕES}

Os resultados obtidos permitem concluir que:

- A estratégia de transformação utilizada permitiu a obtenção de plantas transplastômicas homoplásmicas de fumo pela integração estável do gene marcador seletivo aadA e dos genes s/r0089 e s/r0090 de Synechocystis sp. PCC6803 isoladamente e na forma de operon em genomas plastidiais;

- Da mesma forma, foram obtidas plantas transplastômicas homoplásmicas de tomate pela integração estável do gene marcador seletivo aadA e dos genes slr0089 e s/r0090 de Synechocystis sp. PCC6803 como um operon em genomas plastidiais;

- Plantas transplastômicas homoplásmicas de fumo expressando o gene slr0090 de Synechocystis sp. PCC6803, codificador da enzima HPPD (4hidroxifenil piruvato dioxigenase), mostraram-se mais resistentes ao herbicida isoxaflutole em pré-emergência (in vitro) quando comparadas ao controle não transformado;

- O presente trabalho foi o primeiro esforço de expressão de transgenes para aumento do valor nutricional de plantas buscando o aumento do teor de tocoferóis por manipulação de genomas plastidiais; 
- Pela primeira vez o promotor Patpl foi utilizado para controlar a expressão de transgenes na transformação de genomas plastidiais e os resultados sugerem baixo nivel de expressão quando em comparação aos níveis obtidos em diversos experimentos em literatura com o promotor Prm;

- Identificação de potenciais genes que conferem resistência a herbicidas para expressão em plantas, como observado para o gene s/r0090 de Synechocystis em plastídeos, apresenta enorme potencial de avanço tecnológico na agricultura. 


\section{REFERÊNCIAS BIBLIOGRÁFICAS}

ABID, S.L.;MOUNTS, T.L. Reversed-phase high-performance liquid chromatographic separation of tocopherols. Journal of Chromatography A, v.782, p.25-32, 1997.

AJJAWI, I.; SHINTANI, D. Engineered plants with elevated vitamin E: a nutraceutical success story. TRENDS in Biotechnology, v.22, p.104-107, 2004.

BERGER, I. J. Seqüenciamento e análise de fragmentos cloroplastidiais de tomate para construção de vetores de transformação de cloroplastos via recombinação homóloga. Piracicaba, 2000. 118p. Dissertação (mestrado) Escola Superior de Agricultura Luiz de Queiroz, Universidade de São Paulo.

BOCK, R. Transgenic plastids in basic research and plant biotechnology. Journal of Molecular Biology, v.312, p.425-438, 2001.

BOCK, R.; HAGEMANN, R. Extranuclear Inheritance: Plastid Genetics: Manipulation of plastid genomes and biotechnological applications. Progress in Botany, v.61, p.76-90, 2000.

BOCK, R.; KHAN, M.S. Taming plastids for a green future. TRENDS in Biotechnology, v.22, n.6, p.311-318, 2004. 
BOYTON, J.E.; GILLHAM, N.W.; HARRIS, E,H,; HOSLER, J.P.; JOHNSON, A.M.; JONES, A.R.; RANDOLPH-ANDERSON, B.L.; ROBERTSON, D.; KLEIN, T.M.; SHARK, K.B.; SANFORD, J.C. Chloroplast transformation in Chlamydomonas with high velocity microprojectiles. Science, v.240, p.15341538, 1988.

CARRER, H.; HOCKENBERRY, T.N.; SVAB, Z.; MALIGA, P. Kanamycin resistance as a selectable marker for plastid transformation in tobacco. Molecular and General Genetics, v.241, p.49-56, 1993.

CARRER, H.; MALIGA, P. Targeted insertion of foreign genes into the tobacco plastid genome without physical linkage to the selectable marker gene. Bio/Technology, v.13, p.791-794, 1995.

CERUTTI, H.; OSMAN, M.; GRANDONI, P.; JAGENDORF, A.P. A homolog of Escherichia coli RecA protein in plastids of higher plants. Proceedings of the National Academy of Science USA, v.89, p.8086-8072, 1992.

DANIELL, H.; LEE, S.B.; PANCHAL, T.; WIEBE, P.O. Expression of the native cholera toxin B subunit gene and assembly as functional oligomers in transgenic tobacco chloroplasts. Journal of Molecular Biology, v.31, p.1001-1009, 2001.

DANIELL, H.; KHAN, M.S.; ALLISON, L. Milestones in chloroplast genetic engineering: an environmentally friendly era in biotechnology. TRENDS in Plant Science, v.2, p.84-91, 2002.

DANIELL, H.; RUIZ, O.N.; DHINGRA, A. Chloroplast genetic engineering to improve agronomic traits. Methods in Molecular Biology, v.286, p.111-138, 2005. 
DE COSA, B.; MOAR, W.; LEE, S.B.; MILLER, M.; DANIELL, $H$. Overexpression of the Bt cry2Aa2 operon in chloroplasts leads the formation of insecticidal crystals. Nature Biotechnolology, v.19, p.71-74, 2001.

D'HARLINGUE, A.; CAMARA, B. Plastid enzymes of terpenoid biosynthesis. Purification and characterization of gamma-tocopherol methyltransferase from Capsicum chromoplasts. Journal of Biological Chemistry, v.260, p.15200-15203, 1985.

DOYLE, J.J.; DOYLE, J.L. Plant DNA miniprep. Focus, v.12, p.13-15, 1990.

DUFOURMANTEL, N.; PELISSIER, B.; GARÇON, F.; PELTIER, G.; FERULLO, J.-M.; TISSOT, G. Generation of fertile transplastomic soybean. Plant Molecular Biology, v.55, p.479-489, 2004.

FRASER, P.D.; PINTO, M.E.S.; HOLLOWAY, D.E.; BRAMLEY, P.M. Application of high-performance liquid chromatography with photodiode array detection to the metabolic profiling of plant isoprenoids. The Plant Journal, v.24, n.4, p.551-558, 2000.

FUKUZAWA, K.; TOKUMURA, A; OUCHI, S.; TSUKATANI, H. Antioxidant activities of tocopherols on $\mathrm{Fe}^{2+}$-ascorbate-induced lipid peroxidation in lecithin liposomes. Lipids, v.17, p.511-513, 1982.

GARCIA, I.; RODGERS, M.; LENNE, C.; ROLLAND, A; SAILLAND, A; MATRINGE, M. Subcellular localization and purification of a $p$ hydroxyphenylpuruvate dioxygenase from cultured carrot cells and characterization of the corresponding cDNA. Biochemistry Journal, v.325, p.761-769, 1997. 
GIDDINGS, G; ALLISON, G.; BROOKS, D.; CARTER, A. Transgenic plants as factories for biopharmaceuticals. Nature Biotechnology, v.18, p.1-1155, 2000.

GRAY, M.W. Origin and evolution of organelle genomes. Current Opinion Genetic Development, v.3, p.884-890, 1993.

HAGER, M.; BOCK, R. Enslaved bacteria as new hope for plant biotechnologists. Applied Microbiology and Biotecnology, v.54, p.302$310,2000$.

GÓMEZ-CORONADO, D.J.M.; BARBAS, C. Optimized and validated HPLC method for $\alpha$ - and $\gamma$-tocopherol measurement in Laurus nobilis leaves. New data on tocopherol content. Journal of Agricultural and Food Chemistry, v.51, p.5196-5201, 2003.

GÓMEZ-CORONADO, D.J.M.; IBAÑEZ, E.; RUPÉREZ, F.J.; BARBAS, C. Tocopherol measurement in edible products of vegetable origin. Journal of Chromatography A, v.1054, p.227-233, 2004.

HENSLEY, K.; BENAKSAS, E.J.; BOLLY, R.; COMP, P.; GRAMAS, P.; HAMDHEYDARI, L.; MOU, S.; PYE, Q.N.; STODDARD, M.F.; WALLIS, G.; WILLIAMSON, K.S.; WEST, M.;WECHTER, W.J.; FLOYD, R.A. New perspectives on vitamin $\mathrm{E}$ : $\gamma$-tocopherol and carboxyethylhydroxychroman metabolites in biology and medicine. Free Radical Biology \& Medicine, v.36, p.1-15, 2004.

HIRSCHBERG, J. Production of high-value compounds: carotenoids and vitamin E. Current Opinion in Biotecnology, v.10, p.186-191, 1999. 
HOSOMI, A.; ARITA, M.; SATO, Y.; KIYOSE, C.; UEDA, T.; IGARASHI, 0.;

ARAI, H.; INOUE, K. Affinity for $\alpha$-tocopherol transfer protein as a determinant of the biological activities of vitamin E analogs. FEBS Letters, v.409, p.105-108 1997.

JOB, D. Plant biotechnology in agriculture. Biochimie, v.84, p.1105-1110, 2002.

KAVANAGH, T.A.; THANH, N.D., LAO, N.T., McGRATH, N.; PETER, S.O.; HORVÁTH, E.M.; DIX, P.J.; MEDGYESY, P. Homeologous plastid DNA transformation in tobacco is mediated by multiple recombination events. Genetics, v.152, p.1111-1122, 1999.

KAEMPF-ROTZOLL, D.E.; TRABER, M.G.; ARAI, H. Vitamin E and transfer proteins. Current Opinion in Lipidology, v.14, p.249-254, 2003.

KLEBER-JANKE, T.; KRUPINSKA, $\mathrm{K}$. Isolation of cDNA clones for genes showing enhanced expression in barley leaves during dark-induced senescence as well as during senescence under field conditions Planta, v.203, p.332-340, 1997.

KOCH, M.; LEMKE, R.; HEISE, K.-P.; MOCK, H.-P. Characterization of $\gamma$ tocopherol methyltransferases from Capsicum annuum $\mathrm{L}$ and Arabidopsis thaliana. European Journal of Biochemistry, v.270, p.84-92, 2003.

KOOP, H.-H.; STINMULLER, K.; WAGNER, H.; ROBLER, C.; EIBL, C.; SACHER, L. Integration of foreign sequences into tobacco plastome via polyethilene glycol-mediated protoplast transformation. Planta, v.199, p.193201, 1996. 
KOTA, M.; DANIELL, H.; VARMA, S.; GARCZINKI, S.F.; GOULD, F.; MOAR, W.J. Overexpression of the Bacillus turigiensis (Bt) Cry2Aa2 protein in chloroplasts confers resistance to plants against susceptible and Bt-resistant insects. Proceedures of the Natural Academy of the American Society USA., v.96, p.1840-1845, 1999.

KUMAR, S.; DHINGRA. A.; DANIELL, H. Stable transformation of the cotton plastid genome and maternal inheritance of transgenes. Plant Molecular Biology, v.56, p.203-216, 2004.

KUMAR, S.; DHINGRA. A.; DANIELL, H. Plastid-expressed betaine aldehyde dehydrogenase gene in carrot cultured cells, roots, and leaves confers enhanced salt tolerance. Plant Physiology, v.136, p.2843-2854, 2004.

LEE, D.L.; KNUDSEN, C.G.; MICHAELY, W.J.; CHIN, H.-L.; NGUYEN, N.H.; CARTER, C.G.; CROMARTIE, T.H.; LAKE, B.H.; SHRIBBS, J.M.; FRASER, T. The structure-activity relationships of the triketone class of HPPD herbicides. Pesticide Science, v.54, p.377-384, 1998.

LEE, S.-B.; KWON, H.-B.; KWON, S.-J.; PARK, S.-C.; JEONG, M.-J.; HAN, S.E.; BYUN, M.-O.; DANIELL, H. Accumulation of trehalose within transgenic chloroplasts confers drought tolerance. Molecular Breeding, v.11, p.1-13, 2003.

LUHUA, Z.; YING, T.; ZHENGYU, Z.; GUAGJI, W. Determination of $\alpha$ tocopherol in the traditional chinese medicinal preparation sea buckthorn oil capsule by non-aqueous reversed phase-HPLC. Chemical and Pharmaceutical Bulletin, v.52, p.150-152, 2004. 
MADOKA, Y.; TOMIZAWA, K.-I.; MIZOI, J.; NISHIDA, I.; NAGANO, Y.; SASAKI, $Y$. Chloroplast transformation with modified accD operon increases acetylCoA carboxylase and causes extension of leaf longevity and increase in seed yeald in tobacco. Plant and Cell Physiology, v.43, p.1518-1525, 2002.

MALIGA, P. Towards plastid transformation in flowering plants. Trends in Biotechnology, v.11, p.101-107, 1993.

MALIGA, P. Progress towards commercialization of plastid transformation technology. Trends in Biotechnology, v. 21, p.20-28, 2003.

MALIGA, P. Plastid transformation in higher plants. Annual Reviews in Plant Biology, v.55, 289-313, 2004.

MALIGA, P.; CARRER H.; KANEVSKI, I.; STAUB, J.;SVAB, Z. Plastid engineering in land plants: a conservative genome is open to change. Philosophical and Transactions: Biological Sciences, v.342, p.203-208, 1993.

McBRIDE, K.E.; SVAB, Z.; SCHAAF, D.J.; HOGAN, P.S.; STALKER, D.M.; MALIGA, P. Amplification of a chimeric Bacillus gene in chloroplasts leads to an extraordinary level of an insectidal protein in tobacco. Nature Biotechnology, v.13, p.362-365, 1995.

MEAZZA, G.; SCHEFFLER, B.E.; TELLEZ, M.R.; RIMANDO, A.M.; ROMAGNI, J.G.; DUKE, S.O.; NANAYAKKARA, D.; KHAN, I.A.; ABOURASHED, E.A.; DAYAN, F.E. The inhibitory activity of natural products on plant $\rho$ hydroxyphenylpyruvate dioxygenase. Phytochemistry, v.60, p.281-288, 2002. 
MIYAGI, T.; KAPOOR, S.; SUGITA, M.; SUGIURA, M. Transcript analysis of the tobacco plastid operon rps2/atpl/H/F/A reveal the existence of a nonconsensus type II (NCII) promoter upstream of the atpl coding sequence. Molecular and General Genetics, v.257, p.299-307, 1998.

MOLINA, A.; HERVÁS-STUBBS, S.; DANIELL, H.; MINGO-CASTEL, A.M.; VERAMENDI, J. High-yeald expression of a viral peptide animal vaccine in transgenic tobacco chloroplasts. Plant Biotechnology Journal, v.2, p.141153, 2004.

MORAN, G.R. 4-Hydroxyphenylpyruvate dioxygenase. Archives of Biochemistry and Biophysics, v.433, p.117-128, 2005.

MUNNÉ-BOSCH, S.; FALK, J. New insights into the function of tocopherols in plants. Planta, v.218, n.3, p.323-326, 2003.

MURASHIGE, T.; SKOOG, F. A revised medium for rapid growth and bioassays with tobaco tissue cultures. Physiologia Plantarum, v.15, p.493497, 1962.

NATIONAL RESEARCH COUNCIL OF FOOD AND NUTRITION BOARD, NASNRC Recommended Dietary Allowances. 10.ed., Washington: National Academy Press, 1989, 51p.

NORRIS, S.R.; SHEN, X.;DELLAPENNA, D. Complementation of the Arabidopsis pds 1 mutation wuth the gene encoding $\mathrm{p}$-Hydroxyphenylpyruvate Dioxygenase. Plant Physiology, v.117, p.1317-1323, 1998. 
RUF, S.; HERMANN, M.; BERGER, I.J.; CARRER, H.; BOCK, R. Stable tomato chloroplast transformation results in extremely high levels of gene expression on fruits. Nature Biotecnology, v.19, p.870-875, 2001.

SATO, Y.; HAGIWARA, K.; ARAI, H.; INOUE, K. Purification and characterization of the alpha-tocopherol transfer protein from rat liver. FEBS Letters, v.288, p.41-45, 1991.

SAMBROK, J.; FRITSCH, E.F.; MANIATS, T. Molecular cloning: a laboratory manual, New York: Cold Spring Harbor Laboratory, 2001. 545p.

SCHLEDZ, M.; SEIDLER, A.; BEYER, P.; NEUHAUS, G. A novel phytyltransferase from Synechocystis sp. PCC6803 involved in tocopherol biosynthesis. FEBS Letters, v.499, p.15-20, 2001.

SIDOROV, V.A.; KASTEN, D.; PANG, S.Z.; HAJDUKIEWICZ, P.T.J.; STAUB, J.M.; NEHRA, N.S. Stable chloroplast transformation in potato: use of green fluorescent protein as a plastid marker. Plant Journal, v.19, p.209-219, 1999.

SHINOZAKI, K.; OHME, M.; TANAKA, M.; WAKASUGI, T.; HAYASHIDA, N.; MATSUBAYASHI, T.; ZAITA, N.; CHUNWONGSE, J.; OBOKATA, J.; YAMAGUCHISHINOZAKI, K.; OHTO, C.; TORAZAWA, K.; MENG, B.Y.; SUGITA, M.; DENO, H.; KAMOGASHIRA, T.; YAMADA, K.; KUSUDA, J.; TAKAIWA, F.; KATO, A.; TOHDOH, N.; SHIMADA, H.; SUGIURA, M. The complete nucleotide sequence of the tobacco chloroplast genome: its gene organization and expression. The EMBO Journal, v.5, p.2043-2049. 1986.

SHINTANI, D.; DELLAPENNA, D. Elevating the vitamin E content of plants thrugh metabolic enginneering. Science, v.282, p.2098-2100, 1998. 
SUGIURA, M. The chloroplast genome. Plant Molecular Biology, v.19, p.149168, 1992.

SVAB, Z.; HAJDUKIEWICZ, P.; MALIGA, P. Stable transformation of plastids in higher plants. Proceedings of the National Academy of Science U.S.A., v.87, p.8526-8530, 1990.

SVAB, Z.;MALIGA, P. High-frequency plastid transformation in tobacco by selection for a chimeric aadA gene. Proceedings of the National Academy of Science U.S.A., v.90, p.913-917, 1993.

STAUB, J.M.; GARCIA, B.; GRAVES, J.; HAJDUKIEWICZ, P.T.; NEHRA, N.; PARADKAR, V.; SCHLITTLER, M.; CARROLL, J.A., SPATOLA, L.; WARD, D.; YE, G.; RUSSELL, D.A. High-yield production of a human therapeutic protein in tobacco chloroplasts. Nature Biotechnology, v.18, n.3, p.333$338,2000$.

TORRE, J.; LORENZO, M.P.; MARTÍNEZ-ALCÁZAR, M.P.; BARBAS, C. Simple high-performance method for $\alpha$-tocopherol measurement in Rosmarinus officinalis leaves. New data on $\alpha$-tocopherol content. Journal of Chromatography A, v.919, p.305-311, 2001.

TRABER, M.G.; SIES, H. Vitamin E in humans: demand and delivery. Annual Reviews in Nutrition, v.16, p.321-347, 1996.

TREGONING, J.; MALIGA, P.; DOUGAN, G.; NIXON, P.J. New advances in the production of edible plant vaccines: chloroplast expression of a tetanus vaccine antigen, TetC. Phytochemistry, v.65, p.989-994, 2003. 
VAN EENENNAAM, A.L.; LINCOLN, K.; DURRETT, T.P.; VALENTIN, H.E.; SHEWMAKER, C.K.; THORNE, G.M.; JIANG, J.; BASZIS, S.R.; LEVERING, C.K.; AASEN, E.D.; HAO, M.; STEIN, J.C.; NORRIS, S.R.; LAST, R.L. Engineering vitaming $\mathrm{E}$ content: from Arabidopsis mutant to soy oil. Plant Cell, v.15, p.3007-3019, 2003.

WILLIAMS, J. Isolation of total DNA from Synechocystis PCC6803. Methods in Enzymology, v.167, p.766, 1988.

WHISTANCE, G.R.;THRELFALL, D.R. Biosynthesis of phytoquinones. Homogentisic acid: a precursor of plastoquinones, tocopherols and alphatocopherolquinone in higher plants, green algae and blue-green algae. Biochemistry Journal, v.117, n.3, p.593-600, 1970.

ZHANG, X.H.; BROTHERTON, J.E.; WIDHOLM, J.M.; PORTIS, A.R.Jr. Targeting a nuclear anthranilate synthase alpha-subunit gene to the tobacco plastid genome results in enhanced tryptophan biosynthesis. Plant Physiology, v.127, p.131-141, 2001. 